Article

\title{
Intrinsic Dynamic and Static Nature of $\pi \cdots \pi$ Interactions in Fused Benzene-Type Helicenes and Dimers, Elucidated with QTAIM Dual Functional Analysis
}

\author{
Taro Nishide and Satoko Hayashi *
}

Citation: Nishide, T.; Hayashi, S. Intrinsic Dynamic and Static Nature of $\pi \cdots \pi$ Interactions in Fused Benzene-Type Helicenes and Dimers, Elucidated with QTAIM Dual Functional Analysis. Nanomaterials 2022, 12, 321. https://doi.org/ $10.3390 /$ nano12030321

Academic Editor: Fabien Silly

Received: 15 December 2021

Accepted: 14 January 2022

Published: 19 January 2022

Publisher's Note: MDPI stays neutral with regard to jurisdictional claims in published maps and institutional affiliations.

Copyright: (C) 2022 by the authors. Licensee MDPI, Basel, Switzerland. This article is an open access article distributed under the terms and conditions of the Creative Commons Attribution (CC BY) license (https:// creativecommons.org/licenses/by/ $4.0 /)$.
Faculty of Systems Engineering, Wakayama University, 930 Sakaedani, Wakayama 640-8510, Japan; s209004@wakayama-u.ac.jp

* Correspondence: hayashi3@sys.wakayama-u.ac.jp; Tel.: +81-73-457-8252

\begin{abstract}
The intrinsic dynamic and static nature of the $\pi \cdots \pi$ interactions between the phenyl groups in proximity of helicenes 3-12 are elucidated with the quantum theory of atoms-in-molecules dual functional analysis (QTAIM-DFA). The $\pi \cdots \pi$ interactions appear in $\mathrm{C}-*-\mathrm{C}, \mathrm{H}-*-\mathrm{H}$, and $\mathrm{C}-*-\mathrm{H}$, with the asterisks indicating the existence of bond critical points (BCPs) on the interactions. The interactions of 3-12 are all predicted to have a $p-\mathrm{CS} / \mathrm{vdW}$ nature ( $\mathrm{ddW}$ nature of the pure closed-shell interaction), except for ${ }^{2} \mathrm{C}_{\text {bay }}-*-{ }^{7} \mathrm{C}_{\text {bay }}$ of $\mathbf{1 0}$, which has a $p-\mathrm{CS} / t-\mathrm{HB}_{\mathrm{nc}}$ nature (typical-HBs with no covalency). (See the text for definition of the numbers of $C$ and the bay and cape areas). The natures of the interactions are similarly elucidated between the components of helicene dimers 6:6 and 7:7 with QTAIM-DFA, which have a $p$-CS/vdW nature. The characteristic electronic structures of helicenes are clarified through the natures predicted with QTAIM-DFA. Some bond paths (BPs) in helicenes appeared or disappeared, depending on the calculation methods. The static nature of $\mathrm{C}_{\mathrm{cape}}-*-\mathrm{C}_{\text {cape }}$ is very similar to that of $C_{\text {bay }}-*-C_{\text {bay }}$ in $9-12$, whereas the dynamic nature of $C_{\text {cape }}-*-C_{\text {cape }}$ appears to be very different from that of $\mathrm{C}_{\mathrm{bay}}-*-\mathrm{C}_{\mathrm{bay}}$. The results will be a guide to design the helicene-containing materials of high functionality.
\end{abstract}

Keywords: ab initio calculations; quantum theory of atoms-in-molecules (QTAIM); nonbonded interactions; polycyclic aromatic hydrocarbon $(\mathrm{PAH})$

\section{Introduction}

Helicenes, which are ortho-fused polycyclic aromatic or heteroaromatic compounds with all rings angularly arranged to form helically shaped molecules, are of current and continuing interest. Helicenes are chiral; as a result, they are expected to have specific functionalities. Recently, helicenes have been widely applied in various fields [1-5], such as organic semiconductors [6-10], asymmetric catalysis [11-16], and molecular recognition [17-22], due to their diverse functionalities in materials. Many studies have also been reported on self-assembly phenomena at metal surfaces [23-26] caused by interactions with the $\pi$-orbitals of helicenes. The $\pi$-orbitals will cause intramolecular $\pi \cdots \pi$ interactions between adjacent aromatic rings of helicenes, which play an important role in effective interactions. It is crucial to clarify the nature of $\pi \cdots \pi$ interactions for future high-functioning material developments based on helicenes. The discussion in this paper will be limited to $\pi \cdots \pi$ interactions between the aromatic rings, the nature of which needs to be clarified, since helicenes of the fused benzene type were chosen as the target.

The noncovalent distances between the aromatic planes in close proximity to the helicenes were determined as the total effect of the attractive and repulsive forces between the atoms on the planes. The restoring forces from the deviated planarity in the helicenes should be a main factor for the attractive and repulsive forces due to $\pi$-orbital overlapping in the helicenes. The noncovalent distances between the planes in close proximity to the helicenes are defined as the balanced distances of the two factors. The noncovalent 
intramolecular distances between atoms in close proximity to the helicenes must be (much) shorter than the noncovalent intermolecular distances between the unrestricted nonhelical aromatic species. The shorter distances in helicenes result from the $\pi \cdots \pi$ interactions between the planes in close proximity in space, which operate under very severe conditions. Clarifying the nature of the $\pi \cdots \pi$ interactions in helicenes under such severe conditions will enable us to understand the factors that control the structures and the nature of the interactions. The results will also provide a starting point for understanding the nature of $\pi \cdots \pi$ interactions and will hint at designs for materials with high functionality based on the interactions.

We have been particularly interested in the $\pi \cdots \pi$ interactions that operate under severe conditions, as these should be the factors that control the fine details of the structures. Interactions are also expected to result in materials with high functionalities. The nature of $\pi \cdots \pi$ interactions under such severe conditions was investigated in a series of fused benzene-type helicenes 1-12 and concave-type dimers 6:6-8:8 and 10:10, where 1-3 are analyzed as helicenes in this paper, although they are usually not. Scheme 1 shows the structures of helicenes $\mathbf{1 - 1 2}$, dimers $\mathbf{6 : 6 - 8 : 8 , 1 0 : 1 0}$, and $[n]$ phenacenes $\mathbf{1}_{\mathbf{p}} \mathbf{- 1 2} \mathbf{p}$, where $\mathbf{1}_{\mathbf{p}}-\mathbf{1 2}_{\mathbf{p}}$ are the comparative compounds and $\mathbf{p}$ stands for phenacenes. The bay and cape areas used in this paper are also illustrated. We have previously reported the nature of the benzene $\pi \cdots \pi$ interactions in cyclophanes [27] (see also [28,29]). The $\pi \cdots \pi$ interactions in the helicenes must correspond to the extended $\pi \cdots \pi$ interactions of the species.
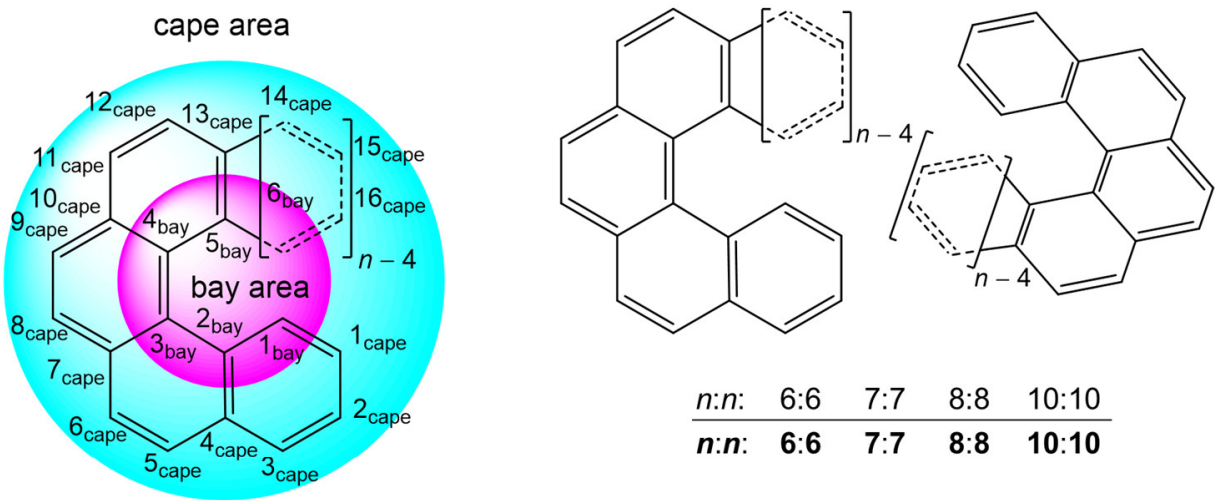

$$
\begin{array}{lllll}
n: n: & 6: 6 & 7: 7 & 8: 8 & 10: 10 \\
\hline \boldsymbol{n}: n: & \mathbf{6 : 6} & \mathbf{7 : 7} & \mathbf{8 : 8} & \mathbf{1 0 : 1 0}
\end{array}
$$

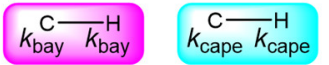

\begin{tabular}{llllllc}
$n:$ & 1 & 2 & 3 & 4 & 5 & 6 \\
\hline$n:$ & $\mathbf{1}$ & $\mathbf{2}$ & $\mathbf{3}$ & $\mathbf{4}$ & $\mathbf{5}$ & $\mathbf{6}$ \\
$n:$ & 7 & 8 & 9 & 10 & 11 & 12 \\
\hline$n:$ & $\mathbf{7}$ & $\mathbf{8}$ & $\mathbf{9}$ & $\mathbf{1 0}$ & $\mathbf{1 1}$ & $\mathbf{1 2}$
\end{tabular}

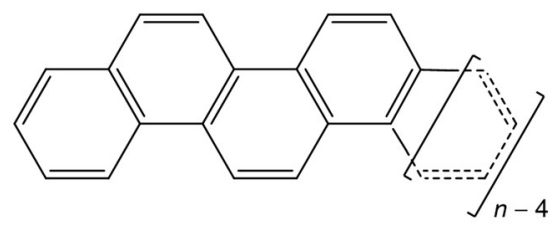

$$
\begin{array}{lllllllllllll}
n: & 1 & 2 & 3 & 4 & 5 & 6 & 7 & 8 & 9 & 10 & 11 & 12 \\
\hline \boldsymbol{n}: & \mathbf{1}_{\mathrm{p}} & \mathbf{2}_{\mathrm{p}} & \mathbf{3}_{\mathrm{p}} & \mathbf{4}_{\mathrm{p}} & \mathbf{5}_{\mathrm{p}} & \mathbf{6}_{\mathrm{p}} & \mathbf{7}_{\mathrm{p}} & \mathbf{8}_{\mathrm{p}} & \mathbf{9}_{\mathrm{p}} & \mathbf{1 0}_{\mathrm{p}} & \mathbf{1 1}_{\mathrm{p}} & \mathbf{1 2}_{\mathrm{p}}
\end{array}
$$

Scheme 1. Helicenes, 1-12, dimers, 6:6-8:8 and 10:10, and $[n]$ phenacenes, $\mathbf{1}_{\mathbf{p}} \mathbf{- 1 2} \mathbf{p}$. The bay and cape areas in 1-12 are illustrated. The number of $\mathrm{C}$ is shown, where the number of $\mathrm{H}$ is the same for $\mathrm{C}-\mathrm{H}$. Benzene, naphthalene, and phenanthrene are defined corresponding to $n=1,2$, and 3 , respectively.

The $\pi \cdots \pi$ interactions in the helicenes were analyzed with QTAIM dual functional analysis (QTAIM-DFA [30-35]), which we proposed based on the QTAIM approach introduced by Bader $[36,37]$. The $\pi \cdots \pi$ interactions will be reproduced on the bond paths (BPs) between atoms, where a bond critical point $(\mathrm{BCP}, *)$ appears on each BP. The $\pi \cdots \pi$ interactions in helicenes are typically described by BPs with BCPs of the $\mathrm{H}-*-\mathrm{H}, \mathrm{C}-*-\mathrm{H}$, and $\mathrm{C}-*-\mathrm{C}$ forms. The asterisk indicates the existence of a BCP in each BP [36,37]. In QTAIM-DFA, $H_{\mathrm{b}}\left(\boldsymbol{r}_{\mathrm{c}}\right)$ is plotted versus $H_{\mathrm{b}}\left(\boldsymbol{r}_{\mathrm{c}}\right)-V_{\mathrm{b}}\left(\boldsymbol{r}_{\mathrm{c}}\right) / 2$, where $H_{\mathrm{b}}\left(\boldsymbol{r}_{\mathrm{c}}\right)$ and $V_{\mathrm{b}}\left(\boldsymbol{r}_{\mathrm{c}}\right)$ are the total electron energy densities and potential energy densities, respectively, at the BCPs of 
the interactions in question. In our treatment, data from the fully optimized structures and the perturbed structures surrounding the fully optimized structures are used for the plots.

Data from the fully optimized structures in the plots were analyzed using polar coordinate $(R, \theta)$ representation, which corresponds to the static nature of the interactions [30-35]. Data from both the perturbed and fully optimized structures are expressed by $\left(\theta_{\mathrm{p}}, \kappa_{\mathrm{p}}\right)$, where $\theta_{\mathrm{p}}$ corresponds to the tangent line and $\kappa_{\mathrm{p}}$ is the curvature of the plot. $\theta$ and $\theta_{\mathrm{p}}$ are measured from the $y$-axis and the $y$-direction, respectively. (See Figure SA1 of the Appendix S1 of the Supporting Information for the definition of the QTAIM-DFA parameters of $(R, \theta)$ and $\left(\theta_{\mathrm{p}}, \kappa_{\mathrm{p}}\right)$, along with Equations (SA3)-(SA6) and the footnotes of Table 1$)$. The concept of the dynamic nature of the interactions was proposed based on $\left(\theta_{\mathrm{p}}, \kappa_{\mathrm{p}}\right)$. The $\theta_{\mathrm{p}}$ and $\kappa_{\mathrm{p}}$ for the major bonds seem to be controlled by the characters of the local bonds in question: The influence from the behaviors of the minor bonds would not be so severe for usual cases.

Table 1. QTAIM Functions and QTAIM-DFA Parameters Evaluated for the Fused Benzene-Type Helicenes of Monomers (3-12), Employing the Perturbed Structures Generated with CIV ${ }^{1-3}$.

\begin{tabular}{|c|c|c|c|c|c|c|c|c|c|}
\hline Species & $\rho_{\mathrm{b}}\left(r_{\mathrm{c}}\right)$ & $c \nabla^{2} \rho_{\mathrm{b}}\left(r_{\mathrm{c}}\right)^{4}$ & $H_{\mathrm{b}}\left(r_{\mathrm{c}}\right)$ & $R^{5}$ & $\theta^{6}$ & $C_{i i}{ }^{7}$ & $\theta_{\mathrm{p}}^{8}$ & $\kappa_{\mathrm{p}}{ }^{9}$ & $\begin{array}{l}\text { Predicted } \\
\text { Nature }\end{array}$ \\
\hline $\mathbf{X}-*-\mathbf{Y}$ & $\left(e a_{0}^{-3}\right)$ & (au) & (au) & (au) & $\left({ }^{\circ}\right)$ & $\left(\AA_{\text {mdyn }}^{-1}\right)$ & $\left({ }^{\circ}\right)$ & $\left(a u^{-1}\right)$ & \\
\hline $3\left({ }^{1} \mathrm{H}_{\mathrm{bay}}-*-{ }^{4} \mathrm{H}_{\mathrm{bay}}\right)$ & 0.0130 & 0.0060 & 0.0020 & 0.0063 & 71.3 & 3.29 & 72.8 & 12.4 & $p-\mathrm{CS} / \mathrm{vdW}$ \\
\hline $4\left({ }^{1} \mathrm{H}_{\text {bay }}-*-{ }^{5} \mathrm{H}_{\text {bay }}\right)$ & 0.0165 & 0.0078 & 0.0026 & 0.0082 & 71.8 & 6.67 & 74.5 & 11.4 & $p-\mathrm{CS} / \mathrm{vdW}$ \\
\hline $5\left({ }^{1} \mathrm{H}_{\text {bay }}-*-{ }^{6} \mathrm{C}_{\mathrm{bay}}\right)$ & 0.0131 & 0.0063 & 0.0021 & 0.0066 & 71.6 & 6.12 & 80.8 & 136 & $p-C S / v d W$ \\
\hline $6\left({ }^{1} \mathrm{H}_{\text {bay }}-*-{ }^{5} \mathrm{C}_{\text {bay }}\right)$ & 0.0131 & 0.0060 & 0.0020 & 0.0063 & 71.3 & 3.82 & 79.9 & 31.8 & $p-\mathrm{CS} / \mathrm{vdW}$ \\
\hline $7\left({ }^{1} \mathrm{H}_{\text {bay }}-*-{ }^{6} \mathrm{C}_{\text {bay }}\right)$ & 0.0135 & 0.0063 & 0.0021 & 0.0067 & 71.5 & 5.47 & 77.9 & 188 & $p-\mathrm{CS} / \mathrm{vdW}$ \\
\hline $7\left({ }^{2} \mathrm{C}_{\text {bay }}-*-{ }^{7} \mathrm{C}_{\text {bay }}\right)$ & 0.0114 & 0.0051 & 0.0017 & 0.0054 & 71.9 & 3.33 & 80.6 & 128 & $p-\mathrm{CS} / \mathrm{vdW}$ \\
\hline $8\left({ }^{1} \mathrm{H}_{\mathrm{bay}}-*-{ }^{6} \mathrm{C}_{\mathrm{bay}}\right)$ & 0.0130 & 0.0061 & 0.0021 & 0.0065 & 71.1 & 5.51 & 76.7 & 189 & $p-C S / v d W$ \\
\hline $8\left({ }^{2} \mathrm{C}_{\text {bay }}-*-{ }^{7} \mathrm{C}_{\text {bay }}\right)$ & 0.0117 & 0.0052 & 0.0017 & 0.0055 & 71.8 & 2.01 & 86.4 & 28.5 & $p-\mathrm{CS} / \mathrm{vdW}$ \\
\hline $9\left({ }^{1} \mathrm{H}_{\text {bay }}-*-{ }^{5} \mathrm{C}_{\text {bay }}\right)$ & 0.0134 & 0.0062 & 0.0022 & 0.0066 & 70.7 & 3.40 & 79.5 & 627 & $p-\mathrm{CS} / \mathrm{vdW}$ \\
\hline $9\left({ }^{2} \mathrm{C}_{\text {bay }}-*-{ }^{7} \mathrm{C}_{\text {bay }}\right)$ & 0.0113 & 0.0050 & 0.0016 & 0.0053 & 72.1 & 1.83 & 81.6 & 119 & $p-\mathrm{CS} / \mathrm{vdW}$ \\
\hline $9\left({ }^{3} \mathrm{C}_{\text {bay }}-*-{ }^{8} \mathrm{C}_{\text {bay }}\right)$ & 0.0122 & 0.0053 & 0.0016 & 0.0056 & 72.9 & 1.87 & 85.0 & 196 & $p-\mathrm{CS} / \mathrm{vdW}$ \\
\hline $9\left({ }^{4} \mathrm{C}_{\text {cape }}{ }^{-*-}{ }^{22} \mathrm{C}_{\text {cape }}\right){ }^{10}$ & 0.0055 & 0.0020 & 0.0007 & 0.0022 & 70.7 & 5.25 & 66.9 & 135 & $p-\mathrm{CS} / \mathrm{vdW}$ \\
\hline $9\left({ }^{6} \mathrm{C}_{\left.\text {cape }^{-*-}{ }^{23} \mathrm{C}_{\text {cape }}\right)}\right)$ & 0.0061 & 0.0021 & 0.0007 & 0.0022 & 70.4 & 8.51 & 69.4 & 37.7 & $p$-CS/vdW \\
\hline $10\left({ }^{1} \mathrm{H}_{\text {bay }}-*-{ }^{6} \mathrm{C}_{\text {bay }}\right)$ & 0.0137 & 0.0064 & 0.0021 & 0.0067 & 71.6 & 5.74 & 79.2 & 123 & $p-\mathrm{CS} / \mathrm{vdW}$ \\
\hline $10\left({ }^{2} \mathrm{C}_{\text {bay }}-*-{ }^{7} \mathrm{C}_{\text {bay }}\right)^{11}$ & 0.0113 & 0.0050 & 0.0018 & 0.0053 & 70.5 & 1.86 & 94.2 & 2890 & $\begin{array}{c}p-\mathrm{CS} / t- \\
\mathrm{HB}_{\mathrm{nc}}\end{array}$ \\
\hline $10\left({ }^{3} \mathrm{C}_{\text {bay }}-*-{ }^{8} \mathrm{C}_{\text {bay }}\right)$ & 0.0114 & 0.0050 & 0.0016 & 0.0053 & 72.1 & 1.78 & 82.0 & 182 & $p-\mathrm{CS} / \mathrm{vdW}$ \\
\hline $10\left({ }^{6} \mathrm{C}_{\text {cape }}-*-{ }^{23} \mathrm{C}_{\text {cape }}\right)$ & 0.0059 & 0.0020 & 0.0007 & 0.0021 & 70.4 & 9.02 & 69.7 & 7.0 & $p-\mathrm{CS} / \mathrm{vdW}$ \\
\hline $10\left({ }^{7} \mathrm{C}_{\text {cape }}{ }^{-*-}{ }^{25} \mathrm{C}_{\text {cape }}\right)$ & 0.0061 & 0.0022 & 0.0008 & 0.0024 & 70.3 & 3.42 & 68.0 & 10.3 & $p-C S / v d W$ \\
\hline $11\left({ }^{1} \mathrm{H}_{\text {bay }}-*-{ }^{6} \mathrm{C}_{\text {bay }}\right)$ & 0.0136 & 0.0063 & 0.0021 & 0.0067 & 71.6 & 5.41 & 79.8 & 113 & $p-C S / v d W$ \\
\hline $11\left({ }^{2} \mathrm{C}_{\text {bay }}-*-{ }^{7} \mathrm{C}_{\text {bay }}\right)$ & 0.0116 & 0.0051 & 0.0017 & 0.0054 & 71.5 & 1.84 & 87.1 & 142 & $p-\mathrm{CS} / \mathrm{vdW}$ \\
\hline $11\left({ }^{3} \mathrm{C}_{\text {bay }}-*-{ }^{8} \mathrm{C}_{\text {bay }}\right)$ & 0.0115 & 0.0050 & 0.0016 & 0.0053 & 72.0 & 1.91 & 82.6 & 166 & $p$-CS/vdW \\
\hline $11\left({ }^{4} \mathrm{C}_{\text {bay }}-*-{ }^{9} \mathrm{C}_{\text {bay }}\right)$ & 0.0111 & 0.0049 & 0.0016 & 0.0052 & 71.7 & 1.69 & 79.5 & 155 & $p-\mathrm{CS} / \mathrm{vdW}$ \\
\hline $11\left({ }^{4} \mathrm{C}_{\text {cape }}{ }^{-*-}{ }^{22} \mathrm{C}_{\text {cape }}\right)$ & 0.0053 & 0.0019 & 0.0007 & 0.0020 & 70.1 & 6.81 & 68.3 & 13.5 & $p-\mathrm{CS} / \mathrm{vdW}$ \\
\hline $11\left({ }^{6} \mathrm{C}_{\text {cape }}{ }^{-*-}{ }^{23} \mathrm{C}_{\text {cape }}\right)$ & 0.0059 & 0.0020 & 0.0007 & 0.0021 & 70.2 & 10.21 & 69.7 & 7.5 & $p-\mathrm{CS} / \mathrm{vdW}$ \\
\hline $11\left({ }^{7} \mathrm{C}_{\text {cape }}-*-{ }^{25} \mathrm{C}_{\text {cape }}\right)$ & 0.0059 & 0.0022 & 0.0008 & 0.0023 & 70.2 & 3.58 & 67.8 & 7.2 & $p-\mathrm{CS} / \mathrm{vdW}$ \\
\hline $11\left({ }^{9} \mathrm{C}_{\text {cape }}{ }^{-*-}{ }^{26} \mathrm{C}_{\text {cape }}\right)$ & 0.0062 & 0.0021 & 0.0007 & 0.0022 & 70.4 & 5.80 & 69.5 & 64.7 & $p-\mathrm{CS} / \mathrm{vdW}$ \\
\hline $12\left({ }^{1} \mathrm{H}_{\text {bay }}-*-{ }^{6} \mathrm{C}_{\text {bay }}\right)$ & 0.0136 & 0.0063 & 0.0021 & 0.0067 & 71.5 & 4.84 & 80.5 & 103 & $p-\mathrm{CS} / \mathrm{vdW}$ \\
\hline $12\left({ }^{2} \mathrm{C}_{\text {bay }}-*-{ }^{7} \mathrm{C}_{\text {bay }}\right)$ & 0.0115 & 0.0051 & 0.0017 & 0.0053 & 71.5 & 1.77 & 87.8 & 349 & $p-C S / v d W$ \\
\hline $12\left({ }^{3} \mathrm{C}_{\text {bay }}-*-{ }^{8} \mathrm{C}_{\text {bay }}\right)$ & 0.0117 & 0.0051 & 0.0016 & 0.0053 & 72.3 & 1.74 & 83.6 & 241 & $p-\mathrm{CS} / \mathrm{vdW}$ \\
\hline $12\left({ }^{4} \mathrm{C}_{\text {bay }}-*-{ }^{9} \mathrm{C}_{\text {bay }}\right)$ & 0.0110 & 0.0048 & 0.0016 & 0.0051 & 71.5 & 1.72 & 80.7 & 87.8 & $p-\mathrm{CS} / \mathrm{vdW}$ \\
\hline $12\left({ }^{4} \mathrm{C}_{\text {cape }}{ }^{-*-}{ }^{22} \mathrm{C}_{\text {cape }}\right)$ & 0.0055 & 0.0020 & 0.0007 & 0.0022 & 70.2 & 4.80 & 66.3 & 697 & $p-\mathrm{CS} / \mathrm{vdW}$ \\
\hline $12\left({ }^{6} \mathrm{C}_{\text {cape }}{ }^{-*-}{ }^{23} \mathrm{C}_{\text {cape }}\right)$ & 0.0060 & 0.0021 & 0.0008 & 0.0022 & 70.0 & 6.78 & 68.0 & 8.6 & $p-\mathrm{CS} / \mathrm{vdW}$ \\
\hline $12\left({ }^{7} \mathrm{C}_{\text {cape }}{ }^{-*-}{ }^{25} \mathrm{C}_{\text {cape }}\right)$ & 0.0059 & 0.0022 & 0.0008 & 0.0023 & 70.0 & 3.41 & 68.2 & 3.3 & $p-\mathrm{CS} / \mathrm{vdW}$ \\
\hline $12\left({ }^{9} \mathrm{C}_{\text {cape }}{ }^{-*-}{ }^{26} \mathrm{C}_{\text {cape }}\right)$ & 0.0059 & 0.0020 & 0.0007 & 0.0021 & 70.3 & 6.95 & 69.4 & 24.7 & $p-C S / v d W$ \\
\hline $12\left({ }^{10} \mathrm{C}_{\left.\mathrm{cape}^{-*-}{ }^{28} \mathrm{C}_{\text {cape }}\right)}\right.$ & 0.0056 & 0.0020 & 0.0007 & 0.0022 & 70.5 & 4.09 & 68.6 & 65.4 & $p$-CS/vdW \\
\hline
\end{tabular}

${ }^{1}$ Calculated with M06-2X/6-311+G(3d,p). ${ }^{2}$ Data are given at the BCPs. ${ }^{3}$ All interactions are predicted to have the $p$-CS/vdW nature, except for $10\left({ }^{2} \mathrm{C}_{\text {bay }}-*-{ }^{7} \mathrm{C}_{\text {bay }}\right)$, which has the $p$-CS $/ t-H B_{\text {nc }}$ nature. ${ }^{4} c \nabla^{2} \rho_{\mathrm{b}}\left(r_{\mathrm{c}}\right)=H_{\mathrm{b}}\left(r_{\mathrm{c}}\right)-$ $V_{\mathrm{b}}\left(r_{\mathrm{c}}\right) / 2$, where $c=\hbar^{2} / 8 m \cdot{ }^{5} R=\left(x^{2}+y^{2}\right)^{1 / 2}$, where $(x, y)=\left(H_{\mathrm{b}}\left(r_{\mathrm{c}}\right)-V_{\mathrm{b}}\left(r_{\mathrm{c}}\right) / 2, H_{\mathrm{b}}\left(\boldsymbol{r}_{\mathrm{c}}\right)\right) \cdot{ }^{6} \theta=90^{\circ}-\tan ^{-1}(y / x) .{ }^{7}$ $C_{i j}=\partial^{2} E / \partial f_{i} \partial f_{j}$, where $i$ and $j$ refer to internal coordinates, and the external force components acting on the system $f_{i}$ and $f_{j}$ correspond to $i$ and $j$, respectively. ${ }^{8} \theta_{\mathrm{p}}=90^{\circ}-\tan ^{-1}(\mathrm{~d} y / \mathrm{d} x) .{ }^{9} \kappa_{\mathrm{p}}=? \mathrm{~d}^{2} y / \mathrm{d} x^{2} ? /\left[1+(\mathrm{d} y / \mathrm{d} x)^{2}\right]^{3 / 2} .{ }^{10}$ Data from $w= \pm 0.0125, \pm 0.025$, and 0 were used for the plot since BCPs were not detected at $w= \pm 0.05 .{ }^{11}$ Data from $w=-0.05,-0.0375,-0.025,-0.0125$, and 0 were used for the plot since BCPs were not detected when $w>0$. 
The perturbed structures necessary for QTAIM-DFA were generated by CIV [38], with the coordinates $C_{i}$ corresponding to the compliance constants $C_{i i}$ for the internal vibrations [39-44]. The basic concept for the compliance constants was introduced by Taylor and Pitzer [45], followed by Konkoli and Cremer [46]. The $C_{i j}$ are defined as the partial second derivatives of the potential energy due to an external force [47-49], where $i$ and $j$ refer to internal coordinates. The dynamic nature of the interactions based on perturbed structures with CIV is described as the "intrinsic dynamic nature of interactions" because the coordinates are invariant to the choice of coordinate system. QTAIM-DFA and the criteria obtained by applying QTAIM-DFA with CIV to standard interactions are explained in the Appendix of the Supporting Information using Schemes SA1-SA3, Figure SA1 and SA2, Table SA1, and Equations (SA1)-(SA7).

In this work, we present the results of the investigations into the natures of the $\pi \cdots \pi$ interactions in 1-12, 6:6-8:8, and 10:10, although some are discussed in the Supporting Information or calculated only for comparison. The interactions are classified and characterized by using the criteria as a reference. The structural features and the energy profile are also discussed to provide a solid basis for the discussion.

\section{Methodological Details of the Calculations}

Calculations were performed with the Gaussian 09 program package [50]. The 6$311+G(3 d, p)$ basis set was used for the calculations at the DFT level of M06-2X [51] (M06$2 X / 6-311+G(3 d, p))$. The optimized structures were confirmed by frequency analysis. The results of the frequency analysis were used to calculate the compliance constants $\left(C_{i i}\right)$ and the coordinates corresponding to $C_{i i}\left(\mathbf{C}_{i}\right)$. Calculations were also performed with M06$2 X / 6-311+G(2 d, p)$ and $L C-\omega P B E / 6-311+G(2 d, p)$ [52] to examine the basis set and level dependence, containing the optimized $\pi \cdots \pi$ distances, on the results. The results with M06$2 X / 6-311+G(3 d, p)$ are discussed in the text, while the results with M06-2X/6-311+G(2d,p) and $L C-\omega P B E / 6-311+G(2 d, p)$ are discussed mainly in the Supporting Information. We should be careful with the basis set and level dependence on the QTAIM-DFA parameters, which has been examined carefully [53]. Similar methodology was also employed for the theoretical studies of the $\pi$-stacking $[54,55]$.

Equation (1) explains the method for generating perturbed structures with CIV [38]. The $i$-th perturbed structure in question $\left(\mathbf{S}_{i w}\right)$ is generated by adding $\mathbf{C}_{i}$ to the standard orientation of a fully optimized structure $\left(\mathbf{S}_{\mathrm{o}}\right)$ in the matrix representation. The coefficient $g_{i w}$ in Equation (1) controls the structural difference between $\mathbf{S}_{i w}$ and $\mathbf{S}_{\mathrm{o}}, g_{i w}$ is determined to satisfy Equation (2) for $r$, where $r$ and $r_{\mathrm{O}}$ stand for the interaction distances in question in the perturbed and fully optimized structures, respectively, with $a_{\mathrm{o}}=0.52918 \AA$ (Bohr radius). Five-digit $\mathbf{C}_{i}$ values were used to predict $\mathbf{S}_{i w}$.

$$
\begin{gathered}
\mathbf{S}_{i w}=\mathbf{S}_{\mathrm{o}}+g_{i w} \cdot \mathbf{C}_{i} \\
r=r_{\mathrm{O}}+w a_{\mathrm{o}}\left(w=(0), \pm 0.025 \text { and } \pm 0.05 ; a_{\mathrm{o}}=0.52918 \AA\right) \\
y=c_{\mathrm{O}}+c_{1} x+c_{2} x^{2}+c_{3} x^{3}\left(R_{\mathrm{c}}{ }^{2}: \text { square of the correlation coefficient }\right)
\end{gathered}
$$

The QTAIM functions were calculated using the same basis set system as in the optimizations, unless otherwise noted, and were analyzed with the AIM2000 [56,57] and AIMAll [58] programs. The $H_{\mathrm{b}}\left(\boldsymbol{r}_{\mathrm{c}}\right)$ values are plotted versus the $H_{\mathrm{b}}\left(\boldsymbol{r}_{\mathrm{c}}\right)-V_{\mathrm{b}}\left(\boldsymbol{r}_{\mathrm{c}}\right) / 2$ values for five data points in Equation (2) in QTAIM-DFA: $w=0, \pm 0.025$, and \pm 0.05 . Each plot was analyzed using a cubic function regression curve, as shown in Equation (3), where $(x$, $y)=\left(H_{\mathrm{b}}\left(\boldsymbol{r}_{\mathrm{c}}\right)-V_{\mathrm{b}}\left(\boldsymbol{r}_{\mathrm{c}}\right) / 2, H_{\mathrm{b}}\left(\boldsymbol{r}_{\mathrm{c}}\right)\right)\left(R_{\mathrm{c}}^{2}>0.99999\right.$ as usual $)$ [31].

\section{Results and Discussion}

\subsection{Structural Features of 1-12 and Their Energy Profile}

The structures of 1-12 were optimized with M06-2X/6-311+G(3d,p), M06-2X/6-311 $+\mathrm{G}(2 \mathrm{~d}, \mathrm{p})$, and LC- $\omega \mathrm{PBE} / 6-311+\mathrm{G}(2 \mathrm{~d}, \mathrm{p})$, retaining $C_{2}$ symmetry. The selected noncovalent $X \cdots Y$ distances $(X, Y=C, H)$ in the optimized structures with M06-2X/6-311+G(3d,p), M06- 
$2 \mathrm{X} / 6-311+\mathrm{G}(2 \mathrm{~d}, \mathrm{p})$, and $\mathrm{LC}-\omega \mathrm{PBE} / 6-311+\mathrm{G}(2 \mathrm{~d}, \mathrm{p})$ are shown in Table $\mathrm{S} 1$ of the Supporting Information, along with the observed values [59-66].

How can the behaviour of the energies of the helicenes be explained? The energies of the helicenes were compared with the energies of $[n]$ phenacene, a nonhelical species, evaluated with M06-2X/6-311+G(3d,p). The energy profiles will be discussed based on the energy differences, $\Delta E(n)=E(n)-E(n-1)$ for helicenes (1-12) and $\Delta E\left(n_{\mathbf{p}}\right)=E\left(n_{\mathbf{p}}\right)-E\left(n_{\mathbf{p}}\right.$ - 1) for $[n]$ phenacenes $\left(\mathbf{1}_{\mathbf{p}}-\mathbf{1 2} \mathbf{p}\right)$. The $\Delta E(n)$ values correspond to the energy differences in the formation of $n$ from $n-1$, and the $\Delta E\left(n_{\mathrm{p}}\right)$ values similarly correspond to $n_{\mathrm{p}}$ from $\left(n_{\mathrm{p}}-\right.$ $1)$. The $E(n), E\left(n_{\mathbf{p}}\right), \Delta E(n)$, and $\Delta E\left(n_{\mathbf{p}}\right)$ values were calculated on the energy surface, which are described by $E_{\mathrm{ES}}(\boldsymbol{n}), E_{\mathrm{ES}}\left(\boldsymbol{n}_{\mathrm{p}}\right), \Delta E_{\mathrm{ES}}(\boldsymbol{n})$, and $\Delta E_{\mathrm{ES}}\left(\boldsymbol{n}_{\mathrm{p}}\right)$, respectively. The values were also calculated with the zero-point energies, which are described by $E_{\mathrm{ZP}}(n), E_{\mathrm{ZP}}\left(n_{\mathrm{p}}\right), \Delta E_{\mathrm{ZP}}(n)$, and $\Delta E_{\mathrm{ZP}}\left(n_{\mathrm{p}}\right)$. The values calculated with M06-2X/6-311+G(3d,p) are collected in Table S2 of the Supporting Information. The plot of $\Delta E_{\mathrm{ZP}}(n)$ versus $\Delta E_{\mathrm{ES}}(n)$ revealed an excellent correlation $\left(y=1.0042 x+0.6859 ; R_{\mathrm{c}}{ }^{2}=0.980\right.$, see Figure $\mathrm{S} 1$ of the Supporting Information). As a result, $\Delta E_{\mathrm{ES}}(n)$ can be used to analyze the energy terms.

Figure 1 shows the plots of $\Delta E_{\mathrm{ES}}(n)$ and $\Delta E_{\mathrm{ES}}\left(n_{\mathrm{p}}\right)$ versus $n$. Both the $\Delta E_{\mathrm{ES}}(n)$ and $\Delta E_{\mathrm{ES}}\left(n_{\mathbf{p}}\right)$ values $\left(\Delta E_{\mathrm{ES}}\left(n ; n_{\mathrm{p}}\right)\right)$ decrease when $n$ increases from 2 to 3 . The extension of the $\pi$ system appears to contribute more to the formation of phenanthrene from naphthalene than the repulsive noncovalent $\mathrm{H} \cdots \mathrm{H}$ interaction. The $\Delta E_{\mathrm{ES}}\left(3 ; 3_{\mathrm{p}}\right)$ values are less than the $\Delta E_{\mathrm{ES}}\left(2 ; 2_{\mathrm{p}}\right)$ values; however, the $\Delta E_{\mathrm{ES}}\left(n ; n_{\mathrm{p}}\right)$ values increase from $3 ; \mathbf{3}_{\mathrm{p}}$ to $4 ; \mathbf{4}_{\mathrm{p}}$. In the case of $\Delta E_{\mathrm{ES}}\left(n_{\mathrm{p}}\right)$, the $\Delta E_{\mathrm{ES}}\left(\mathbf{4}_{\mathrm{p}}\right)$ value is somewhat larger than $\Delta E_{\mathrm{ES}}\left(\mathbf{3}_{\mathrm{p}}\right)$ but slightly smaller than $\Delta E_{\mathrm{ES}}\left(\mathbf{2}_{\mathrm{p}}\right)$. The $\Delta E_{\mathrm{ES}}\left(\boldsymbol{n}_{\mathrm{p}}\right)$ value decreases again slightly from $\mathbf{4}_{\mathrm{p}}$ to $\mathbf{5}_{\mathrm{p}}$. Then, the values are nearly constant for $n_{\mathrm{p}} \geq \mathbf{5}_{\mathrm{p}}$. The results show that the repulsive energy from the noncovalent $\mathrm{H} \cdots \mathrm{H}$ interaction does not appear to be as severe as the stabilization factor from the extended $\pi$ systems in $\mathbf{1}_{\mathbf{p}} \mathbf{- 1 2} \mathbf{p}$. Namely, the $\boldsymbol{n}_{\mathbf{p}}$ system stabilizes almost constantly as the size of the species increase, especially for $n_{\mathbf{p}} \geq \mathbf{5}_{\mathbf{p}}$, although a change in $\Delta E_{\mathrm{ES}}\left(\boldsymbol{n}_{\mathrm{p}}\right)$ is detected for $\boldsymbol{2}_{\mathrm{p}} \leq \boldsymbol{n}_{\mathrm{p}}<\mathbf{5}_{\mathrm{p}}$.

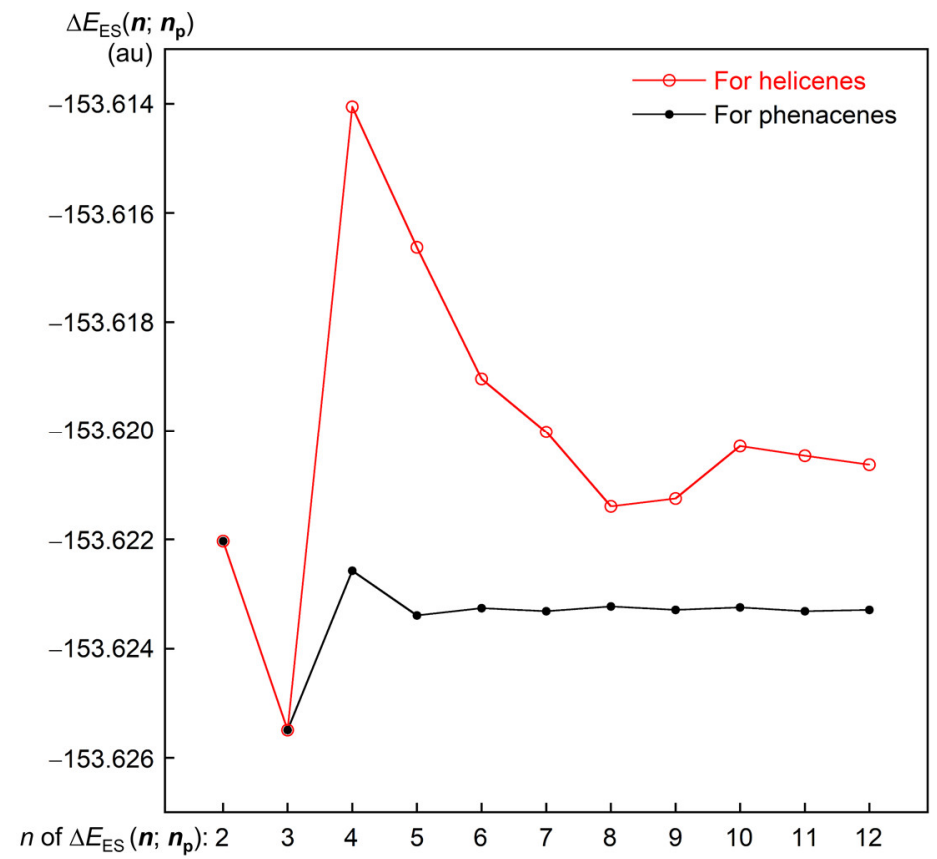

Figure 1. Plot of $\Delta E_{\mathrm{ES}}(n)$ and $\Delta E_{\mathrm{ES}}\left(n_{\mathrm{p}}\right)$ versus $n$, evaluated with $\mathrm{M} 06-2 \mathrm{X} / 6-311+\mathrm{G}(3 \mathrm{~d}, \mathrm{p})$, where $\Delta E_{\mathrm{ES}}(\boldsymbol{n})=E_{\mathrm{ES}}(\boldsymbol{n})-E_{\mathrm{ES}}(\boldsymbol{n}-1)$ and $\Delta E_{\mathrm{ES}}\left(n_{\mathrm{p}}\right)=E_{\mathrm{ES}}\left(n_{\mathrm{p}}\right)-E_{\mathrm{ES}}\left(n_{\mathrm{p}}-1\right)$.

The data points for $\Delta E_{\mathrm{ES}}(n)$ appear to be greater than those for $\Delta E_{\mathrm{ES}}\left(n_{\mathrm{p}}\right)$ when $n \geq 4$. The observations must be due to the severe steric repulsion in $\Delta E_{\mathrm{ES}}(\boldsymbol{n} \geq 4)$, where the plot for $\Delta E_{\mathrm{ES}}\left(n_{\mathrm{p}}\right)$ corresponds to that without such severe steric repulsion. The $\Delta E_{\mathrm{ES}}(4)$ value is 
much larger than those of $\Delta E_{\mathrm{ES}}(2)$ and $\Delta E_{\mathrm{ES}}(3)$. The results can be explained by considering the much larger contribution from the repulsive noncovalent $\mathrm{H} \cdots \mathrm{H}$ interaction in 4 than in 3. This consideration is supported by the optimized structure of 4 , drawn in Figure 2, as the molecular graph type. The $\Delta E_{\mathrm{ES}}(n)$ values decrease in the following order: $\Delta E_{\mathrm{ES}}(4)>$ $\Delta E_{\mathrm{ES}}(5)>\Delta E_{\mathrm{ES}}(6)>\Delta E_{\mathrm{ES}}(7)>\Delta E_{\mathrm{ES}}(\mathbf{8})$. The contribution of steric repulsion to $\Delta E_{\mathrm{ES}}(\boldsymbol{n})$ due to noncovalent interactions is expected to increase as $n$ increases in this process. However, the observed results are the opposite of what was expected. Therefore, the observed trend should be attributed to the increased energy-lowering effect by the extended $\pi$ systems in 4-8 relative to the repulsive interactions.

(a)

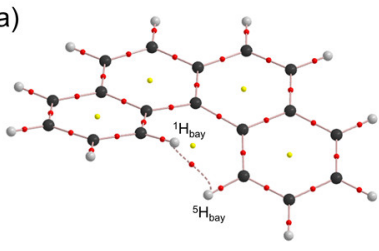

(b)

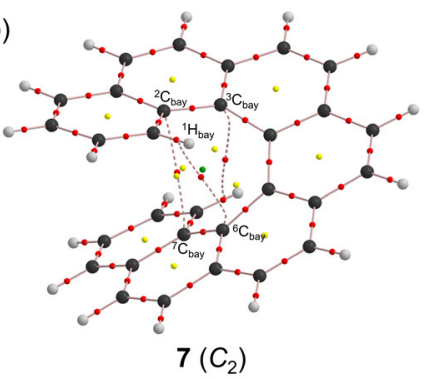

(c)

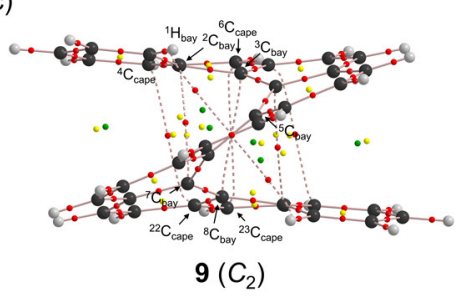

(d)

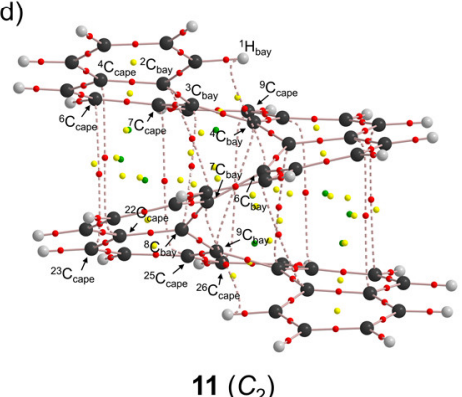

(e)

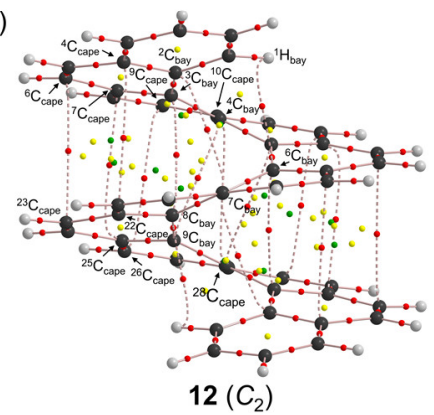

Figure 2. Molecular graphs for 4 (a), 7 (b), 9 (c), 11 (d), and 12 (e), calculated with M06-2X/6$311+\mathrm{G}(3 \mathrm{~d}, \mathrm{p})$, where BPs with BCPs corresponding to intramolecular noncovalent interactions are detected. The BCPs are denoted by red dots, RCPs (ring critical points) by yellow dots, CCPs (cage critical points) by green dots, and BPs by pink lines. The carbon atoms are in black and the hydrogen atoms are in grey.

The $\Delta E_{\mathrm{ES}}(\boldsymbol{n})$ value becomes somewhat larger again from $\boldsymbol{n}=\mathbf{8}$ to 9 and 9 to 10 , and then decreases again from $\mathbf{1 0}$ to $\mathbf{1 1}$ and $\mathbf{1 1}$ to $\mathbf{1 2}$. The subtle conditions in the steric repulsion contribute to the complex behaviour of $\Delta E_{\mathrm{ES}}(n)(8 \leq n \leq 12)$. The behaviour of $\Delta E_{\mathrm{ES}}(\mathbf{2})-\Delta E_{\mathrm{ES}}(\mathbf{1 2})$ shown in Figure 1 should be affected both by the repulsive factor of the noncovalent $\mathrm{H}-*-\mathrm{H}, \mathrm{C}-*-\mathrm{H}$, and $\mathrm{C}-*-\mathrm{C}$ interactions and by the energy-lowering factor of the extended $\pi$ system. The $\Delta E_{\mathrm{ES}}(4)$ value is the largest among $\Delta E_{\mathrm{ES}}(\mathbf{2})-\Delta E_{\mathrm{ES}}(\mathbf{1 2})$. The results are of great interest since the repulsive noncovalent $\mathrm{H} \cdots \mathrm{H}$ interaction in 4 from 3 appears to be very large among $\mathbf{2 - 1 2}$ when evaluated by $\Delta E_{\mathrm{ES}}(\boldsymbol{n})$. The trend in $\Delta E_{\mathrm{ES}}(\boldsymbol{n})$ seems to be in good agreement with those reported by Rulíšek et al., calculated with PBE-D/TZVP//PBE-D/6-31G(d), except for $\Delta E_{\mathrm{ES}}(8)$ and $\Delta E_{\mathrm{ES}}(9)$ [67].

It is also instructive to analyze the aromaticities of acenes, phenacenes, and helicenes after investigating the energy profiles. The structures of acenes, phenacenes, and helicenes are illustrated in Chart S1 of the Supporting Information, together with the definition of the ring positions. The aromaticities were analyzed by the HOMA (harmonic oscillator model of aromaticity) method [68]. The HOMA values are collected in Table S3 of the Supporting Information. The HOMA values of the acenes and phenacenes are plotted versus those of the helicenes, which are shown in Figure S2 of the Supporting Information. The plot of the data for phenacenes versus those for helicenes gave a very good correlation $(y=0.964 x+$ $\left.0.042 ; R_{\mathrm{c}}{ }^{2}=0.981\right)$, whereas the correlations of the plots for acenes versus helicenes were very poor $\left(y=-0.685 x+0.995 ; R_{\mathrm{c}}{ }^{2}=0.492\right.$ if calculated under the closed-shell singlet 
conditions and $y=-0.399 x+0.880 ; R_{\mathrm{C}}{ }^{2}=0.317$ under the open-shell singlet conditions). The very good correlation of the former demonstrates that the aromaticities of the helicenes appear to be very similar to those of the phenacenes, irrespective of the very severe steric deformations in the structures of helicenes. However, the very poor correlations with the negative correlation constants show that the aromaticities of the helicenes are very different from those of acenes.

\subsection{Survey of $X-*-Y(X, Y=C$ and $H)$ in 3-12 with the Molecular Graphs}

Figure 2 shows the molecular graphs, exemplified by 4, 7, 9, 11, and 12. Many BPs with BCPs are detected in the $\pi \cdots \pi$ interactions between the phenyl rings in close proximity to the helicenes. The molecular graphs for helicenes 3-12, except for 4, 7, 9, 11, and 12, are shown in Figure S3 of the Supporting Information.

The BPs corresponding to $\mathrm{X}-*-\mathrm{Y}(\mathrm{X}, \mathrm{Y}=\mathrm{C}$ and $\mathrm{H})$ appear almost straight, as shown in Figure 2 and Figure S4 of the Supporting Information, although some appear somewhat bent. To examine the linearity of the BPs further, the lengths of the BPs $\left(r_{\mathrm{BP}}\right)$ were calculated for all $\mathrm{X}-*-\mathrm{Y}$ of $\mathbf{3 - 1 2}$, along with the corresponding straight-line distances $\left(R_{\mathrm{SL}}\right)$. The values are collected in Table S4 of the Supporting Information, along with the differences between them $\left(\Delta r_{\mathrm{BP}}=r_{\mathrm{BP}}-R_{\mathrm{SL}}\right)$. The averaged values of $\Delta r_{\mathrm{BP}}$ were $0.2040,0.4006,0.0588$, and $0.1451 \AA$ for $\mathrm{H}_{\text {bay }}-*-\mathrm{H}_{\text {bay }}, \mathrm{C}_{\text {bay }}-*-\mathrm{H}_{\text {bay }}, \mathrm{C}_{\text {bay }}-*-\mathrm{C}_{\text {bay }}$, and $\mathrm{C}_{\text {cape }}-*-\mathrm{C}_{\text {cape }}$, respectively. As a result, $\Delta r_{\mathrm{BP}}$ for $\mathrm{H}_{\mathrm{bay}}-*-\mathrm{H}_{\text {bay }}$ and $\mathrm{C}_{\text {bay }}-*-\mathrm{H}_{\text {bay }}$ were larger than $0.20 \AA$, while those for $\mathrm{C}_{\text {bay }}-*-\mathrm{C}_{\text {bay }}$ and $\mathrm{C}_{\text {cape }}-*-\mathrm{C}_{\text {cape }}$ were less than $0.15 \AA$. Therefore, the BPs corresponding to $\mathrm{C}_{\text {bay }}-*-\mathrm{C}_{\text {bay }}$ and $\mathrm{C}_{\text {cape }}-*-\mathrm{C}_{\text {cape }}$ can be roughly approximated as straight lines since the $\Delta r_{\mathrm{BP}}$ values are less than $0.20 \AA$ (see also Figure S4 of the Supporting Information).

The QTAIM functions were calculated at BCPs on X-*-Y of 3-12 with M06-2X/6$311+\mathrm{G}(3 \mathrm{~d}, \mathrm{p})$. Table 1 collects the $\rho_{\mathrm{b}}\left(r_{\mathrm{c}}\right), H_{\mathrm{b}}\left(r_{\mathrm{c}}\right)-V_{\mathrm{b}}\left(r_{\mathrm{c}}\right) / 2$, and $H_{\mathrm{b}}\left(r_{\mathrm{c}}\right)$ values for one of the $\mathrm{X}-*-\mathrm{Y}$ if it is doubly degenerated due to the $C_{2}$ symmetry of the optimized structures. Figure 3 shows the plots of $H_{\mathrm{b}}\left(\boldsymbol{r}_{\mathrm{c}}\right)$ versus $H_{\mathrm{b}}\left(\boldsymbol{r}_{\mathrm{c}}\right)-V_{\mathrm{b}}\left(\boldsymbol{r}_{\mathrm{c}}\right) / 2$ for each $\mathrm{X}-*-\mathrm{Y}$, exemplified by $3-6,8,10$, and 12, where $\mathrm{H}-*-\mathrm{H}$ was detected in 3 and 4 and $\mathrm{C}-*-\mathrm{H}$ and $\mathrm{C}-*-\mathrm{C}$ were detected in 8, 10, and 12. (See Figure S5 of the Supporting Information for 7, 9, and 11).
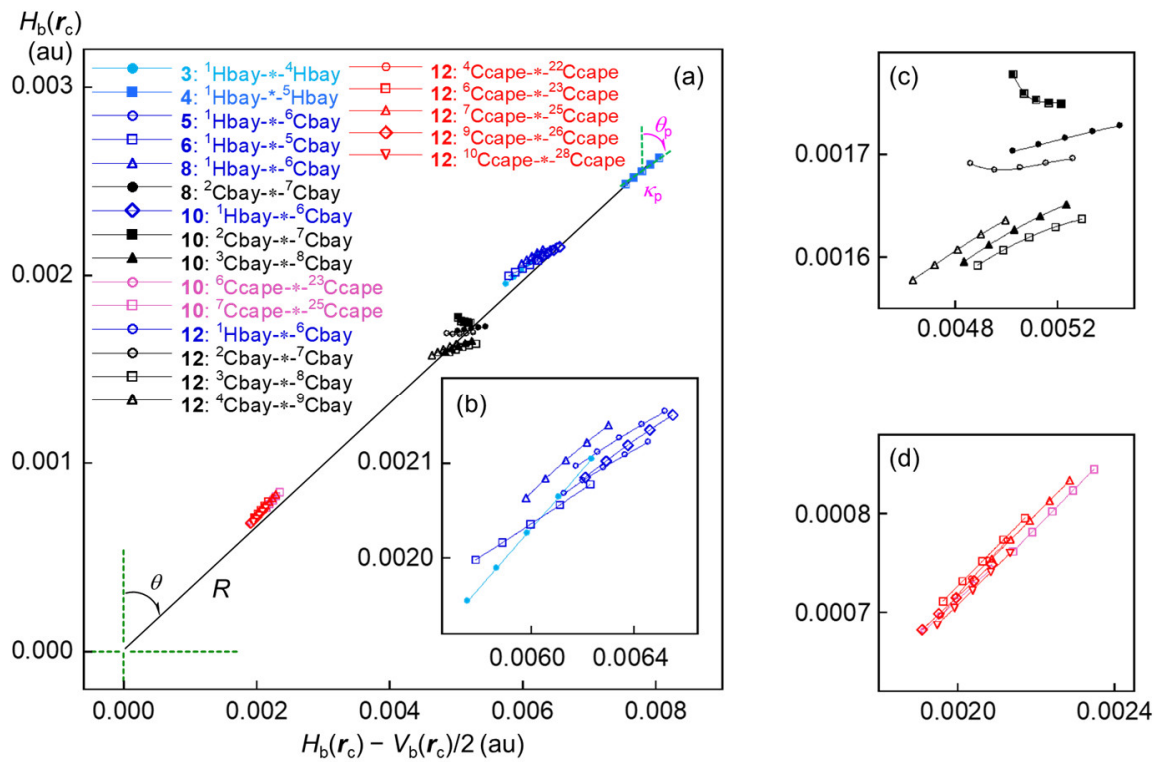

Figure 3. Plots of $H_{\mathrm{b}}\left(r_{\mathrm{c}}\right)$ versus $H_{\mathrm{b}}\left(r_{\mathrm{c}}\right)-V_{\mathrm{b}}\left(\boldsymbol{r}_{\mathrm{c}}\right) / 2$ for $\mathrm{H}-*-\mathrm{H}, \mathrm{C}-*-\mathrm{H}$, and $\mathrm{C}-*-\mathrm{C}$, exemplified by those in 3-6, 8, 10, and 12. (a) Whole picture; (b) Magnified picture of the $\mathrm{C}-*-\mathrm{H}$ area; (c) Magnified picture of the $\mathrm{C}-*-\mathrm{C}$ bay area; (d) Magnified picture of the $\mathrm{C}-*-\mathrm{C}$ cape area. The definitions of $(R, \theta)$ and $\left(\theta_{\mathrm{p}}\right.$, $\kappa_{\mathrm{p}}$ ) are illustrated, exemplified by $\mathrm{H}-*-\mathrm{H}$ in 4. 
The plots were analyzed according to Equations (SA3)-(SA6) of the Supporting Information. Table 1 also collects the QTAIM-DFA parameters of $(R, \theta)$ and $\left(\theta_{\mathrm{p}}, \kappa_{\mathrm{p}}\right)$ for each $\mathrm{X}-*-\mathrm{Y}$ of 3-12, along with the $C_{i i}$ values corresponding to the interactions in question. The $\left(\theta_{\mathrm{p}}, \kappa_{\mathrm{p}}\right)$ values, evaluated with CIV, should be denoted by $\left(\theta_{\mathrm{p}: \mathrm{CIV}}, \kappa_{\mathrm{p}: \mathrm{CIV}}\right)$, respectively. However, $\left(\theta_{\mathrm{p}}, \kappa_{\mathrm{p}}\right)$ will be used in place of $\left(\theta_{\mathrm{p}: \text { CIV }}, \kappa_{\mathrm{p}: \text { CIV }}\right)$ to simplify the notation. The QTAIM functions and QTAIM-DFA parameters calculated with M06-2X/6-311+G(2d,p) and LC$\omega \mathrm{PBE} / 6-311+\mathrm{G}(2 \mathrm{~d}, \mathrm{p})$ are collected in Tables S5 and S6 of the Supporting Information respectively.

\subsection{Nature of Each $X-*-Y$ in $\mathbf{3 - 1 2}$}

The criteria shown in Scheme SA3 and Table SA1 of the Supporting Information indicate that the interactions in the range of $45^{\circ}<\theta<90^{\circ}$ should be classified as pure closed-shell ( $p$-CS) interactions. In the $p$-CS region of $45^{\circ}<\theta<90^{\circ}$, the character of the interactions will be the vdW type for $45^{\circ}<\theta_{\mathrm{p}}<90^{\circ}\left(45^{\circ}<\theta<75^{\circ}\right)$, whereas the character of the interactions will be the typical hydrogen bond type $(t-\mathrm{HB})$ with no covalency $\left(t-\mathrm{HB}_{\mathrm{nc}}\right)$ for $90^{\circ}<\theta_{\mathrm{p}}<125^{\circ}\left(75^{\circ}<\theta<90^{\circ}\right)$, where $\theta=75^{\circ}$ and $\theta_{\mathrm{p}}=125^{\circ}$ are tentatively given for $\theta_{\mathrm{p}}$ $=90^{\circ}$ and $\theta=90^{\circ}$, respectively.

The $C$ atoms in helicenes 3-12 were subdivided into $C_{\text {bay }}$ and $C_{\text {cape }}$ based on the positions of the atoms in the species, as were the $\mathrm{H}$ atoms into $\mathrm{H}_{\text {bay }}$ and $\mathrm{H}_{\text {cape. The bay }}$ and cape areas (positions) in the species are illustrated in Scheme 1. While both the $C_{\text {bay }}$ and $\mathrm{C}_{\text {cape }}$ atoms of 3-12 participate in the interactions as BPs, only $\mathrm{H}_{\text {bay }}$ atoms participate as BPs. The $\theta$ and $\theta_{\mathrm{p}}$ values for $\mathrm{H}-*-\mathrm{H}, \mathrm{C}-*-\mathrm{H}$, and $\mathrm{C}-*-\mathrm{C}$ of $\mathbf{3}-\mathbf{1 2}$, collected in Table 2 , are all less than $90^{\circ}$, except for $\theta_{\mathrm{p}}$ of ${ }^{2} \mathrm{C}_{\text {bay }}{ }^{-{ }^{7}}{ }^{7} \mathrm{C}_{\text {bay }}$ in 10 , where $\left(\theta, \theta_{\mathrm{p}}\right)=\left(70.5^{\circ}, 94.2^{\circ}\right)$. The ${ }^{2} \mathrm{C}_{\text {bay }}-{ }_{-}-{ }^{7} \mathrm{C}_{\text {bay }}$ interaction in $\mathbf{1 0}$ is denoted by $\mathbf{1 0}\left({ }^{2} \mathrm{C}_{\text {bay }}-{ }^{-7} \mathrm{C}_{\text {bay }}\right)$ (see also Table 1$)$. Therefore, the $\mathrm{H}-*-\mathrm{H}, \mathrm{C}-*-\mathrm{H}$, and $\mathrm{C}-*-\mathrm{C}$ interactions of 3-12 are all classified as $p-\mathrm{CS}$ interactions and characterized to have a vdW nature, which is denoted by $p$-CS/vdW, except for 10 $\left({ }^{2} \mathrm{C}_{\mathrm{bay}}-{ }^{-}{ }^{7} \mathrm{C}_{\mathrm{bay}}\right)$, which is predicted to have a $p-\mathrm{CS} / t-\mathrm{HB}_{\mathrm{nc}}$ nature.

Table 2. QTAIM Functions and QTAIM-DFA Parameters Evaluated for the Fused Benzene-Type Helicenes of Concave-Type Dimers (6:6 and 7:7), Employing the Perturbed Structures Generated with $\mathrm{CIV}^{1-3}$.

\begin{tabular}{|c|c|c|c|c|c|c|c|c|c|}
\hline Species & $\rho_{\mathrm{b}}\left(r_{\mathrm{c}}\right)$ & $c \nabla^{2} \rho_{\mathrm{b}}\left(r_{\mathrm{c}}\right)$ & $H_{\mathrm{b}}\left(r_{\mathrm{c}}\right)$ & $R$ & $\theta$ & $C_{i i}$ & $\theta_{\mathrm{p}}$ & $\kappa_{\mathrm{p}}$ & $\begin{array}{l}\text { Predicted } \\
\text { Nature }\end{array}$ \\
\hline $\mathbf{X}-*-\mathbf{Y}$ & $\left(e a_{\mathrm{o}}{ }^{-3}\right)$ & (au) & (au) & (au) & $\left({ }^{\circ}\right)$ & $\left(\AA ̊\right.$ mdyn $\left.^{-1}\right)$ & $\left({ }^{\circ}\right)$ & $\left(\mathrm{au}^{-1}\right)$ & \\
\hline 6:6 $\left({ }^{1} \mathrm{H}_{\text {bay }-*-}{ }^{17^{\prime}} \mathrm{H}_{\text {cape }}\right)^{4}$ & 0.0045 & 0.0018 & 0.0006 & 0.0019 & 72.6 & 25.02 & 88.1 & 5163 & $p$-CS/vdW \\
\hline $\mathbf{6 : 6}\left({ }^{1} \mathrm{H}_{\text {cape }-*-{ }^{-*}} \mathrm{H}_{\text {cape }}\right)$ & 0.0061 & 0.0022 & 0.0006 & 0.0023 & 74.3 & 35.63 & 76.2 & 184.2 & $p-\mathrm{CS} / \mathrm{vdW}$ \\
\hline $6: 6\left({ }^{1} \mathrm{H}_{\text {cape }}{ }^{-*-}{ }^{16} \mathrm{H}_{\text {cape }}\right)$ & 0.0051 & 0.0019 & 0.0007 & 0.0020 & 70.9 & 42.01 & 74.9 & 69.9 & $p$-CS/vdW \\
\hline 6:6 $\left({ }^{15} \mathrm{C}_{\text {cape }}{ }^{-*-}{ }^{17^{\prime}} \mathrm{C}_{\text {cape }}\right)^{5}$ & 0.0065 & 0.0025 & 0.0009 & 0.0027 & 69.2 & 12.64 & 70.8 & 1066 & $p-\mathrm{CS} / \mathrm{vdW}$ \\
\hline $6: 6\left({ }^{16} \mathrm{C}_{\text {cape }}{ }^{-*-1}-1 \mathrm{C}_{\text {cape }}\right)$ & 0.0066 & 0.0026 & 0.0010 & 0.0028 & 68.3 & 8.63 & 68.0 & 53.5 & $p$-CS/vdW \\
\hline $6: 6\left({ }^{1} \mathrm{H}_{\text {bay }}-*-{ }^{5} \mathrm{C}_{\text {bay }}\right)$ & 0.0128 & 0.0057 & 0.0019 & 0.0060 & 71.9 & 3.817 & 78.3 & 32.3 & $p-C S / v d W$ \\
\hline $6: 6\left({ }^{3} \mathrm{C}_{\text {bay }}-*-{ }^{7} \mathrm{H}_{\text {bay }}\right)$ & 0.0134 & 0.0061 & 0.0020 & 0.0064 & 71.7 & 3.414 & 79.3 & 29.5 & $p-\mathrm{CS} / \mathrm{vdW}$ \\
\hline 7:7 $\left({ }^{20} \mathrm{H}_{\left.\text {cape }^{-*-}-{ }^{18^{\prime}} \mathrm{H}_{\text {cape }}\right)}\right.$ & 0.0073 & 0.0031 & 0.0012 & 0.0033 & 68.9 & 14.61 & 75.5 & 24.6 & $p$-CS/vdW \\
\hline $7: 7\left({ }^{20} \mathrm{H}_{\text {cape }}{ }^{-*-20}{ }^{20} \mathrm{H}_{\text {cape }}\right)$ & 0.0054 & 0.0022 & 0.0008 & 0.0024 & 70.0 & 27.90 & 72.7 & 36.5 & $p$-CS/vdW \\
\hline $7: 7\left({ }^{20} \mathrm{H}_{\text {cape }}{ }^{-*-}{ }^{\prime} \mathrm{C}_{\text {cape }}\right)$ & 0.0079 & 0.0030 & 0.0010 & 0.0032 & 71.4 & 10.01 & 73.3 & 125.7 & $p$-CS/vdW \\
\hline $7: 7\left({ }^{18} \mathrm{H}_{\text {cape }}{ }^{-*-}{ }^{3} \mathrm{C}_{\text {cape }}\right)$ & 0.0050 & 0.0016 & 0.0005 & 0.0016 & 73.8 & 17.36 & 73.2 & 181.8 & $p$-CS/vdW \\
\hline $7: 7\left({ }^{1} \mathrm{H}_{\text {bay }}-*-{ }^{6} \mathrm{C}_{\mathrm{bay}}\right)$ & 0.0132 & 0.0062 & 0.0021 & 0.0065 & 70.8 & 5.557 & 80.0 & 93.5 & $p-\mathrm{CS} / \mathrm{vdW}$ \\
\hline $7: 7\left({ }^{3} \mathrm{C}_{\text {bay }}-*-{ }^{8} \mathrm{H}_{\text {bay }}\right)$ & 0.0138 & 0.0065 & 0.0021 & 0.0068 & 71.9 & 5.024 & 78.8 & 154.1 & $p-\mathrm{CS} / \mathrm{vdW}$ \\
\hline
\end{tabular}

${ }^{1}$ Calculated with M06-2X/6-311+G(3d,p). ${ }^{2}$ Data are given at the BCPs. ${ }^{3}$ See footnotes of Table 1 for the QTAIM-DFA parameters and $C_{i i}{ }^{4}$ Data from $w=-0.0375,-0.025,-0.0125,0$, and 0.0125 were used for the plot, since BCPs for 6:6 $\left({ }^{1} \mathrm{H}_{\text {bay }}-*-{ }^{17} \mathrm{H}_{\text {cape }}\right)$ were not detected when $w>0.0125 .{ }^{5}$ Data from $w=-0.05,-0.0375,-0.025$, -0.0125 , and 0 were used for the plot, since BCPs for $6: 6\left({ }^{15} \mathrm{C}_{\text {cape }}{ }^{-*-1}{ }^{17} \mathrm{C}_{\text {cape }}\right)$ were not detected when $w>0$.

Next, the interactions were individually examined. The $\left(\theta, \theta_{\mathrm{p}}\right)$ values are $\left(71.3^{\circ}, 72.8^{\circ}\right)$ and $\left(71.8^{\circ}, 74.5^{\circ}\right)$ for $3\left({ }^{1} \mathrm{H}_{\text {bay }}-{ }^{-}{ }^{4} \mathrm{H}_{\text {bay }}\right)$ and $4\left({ }^{1} \mathrm{H}_{\text {bay }}-{ }^{-}{ }^{5} \mathrm{H}_{\text {bay }}\right)$, respectively. The $\theta$ values for $3\left({ }^{1} \mathrm{H}_{\text {bay }}-{ }^{4} \mathrm{H}_{\mathrm{bay}}\right)$ and $4\left({ }^{1} \mathrm{H}_{\mathrm{bay}}-{ }^{-5} \mathrm{H}_{\mathrm{bay}}\right)$ are larger than those of $\mathrm{A}-*-\mathrm{HF}(\mathrm{A}=\mathrm{He}, \mathrm{Ne}$, and $\left.\operatorname{Ar}:\left(\theta, \theta_{\mathrm{p}}\right)=\left(59.9-70.9^{\circ}, 64.0-88.0^{\circ}\right)\right)$, whereas the $\theta_{\mathrm{p}}$ values are larger than those of 
$\mathrm{A}-*-\mathrm{HF}(\mathrm{A}=\mathrm{He}$ and Ar). The interaction in 4 is estimated to be slightly stronger than that in 3 , although the real image of $3\left({ }^{1} \mathrm{H}_{\text {bay }}{ }^{-*-}{ }^{4} \mathrm{H}_{\text {bay }}\right)$ has been much debated [69-71]. The detection of BPs with BCPs for $3\left({ }^{1} \mathrm{H}_{\text {bay }}{ }^{-*}-{ }^{4} \mathrm{H}_{\text {bay }}\right)$ would not show enough strength for the interaction. It could be the mathematical results of the treatment. Nevertheless, 3 $\left({ }^{1} \mathrm{H}_{\text {bay }}-{ }^{4}{ }^{4} \mathrm{H}_{\text {bay }}\right)$ and $4\left({ }^{1} \mathrm{H}_{\text {bay }} *-{ }^{5} \mathrm{H}_{\text {bay }}\right)$ are discussed as very weak interactions in this work because the $\left(\theta, \theta_{\mathrm{p}}\right)$ values are larger than those of $\mathrm{A}-*-\mathrm{HF}(\mathrm{A}=\mathrm{He}, \mathrm{Ne}$, and $\mathrm{Ar})$. Double $\mathrm{H}_{\text {bay }}-*-\mathrm{C}_{\text {bay }}$ interactions are detected for each of 5-12, with $\left(\theta, \theta_{\mathrm{p}}\right)$ values of $\left(70.7-71.6^{\circ}\right.$, $\left.76.7-80.8^{\circ}\right)$. The $\left(\theta, \theta_{\mathrm{p}}\right)$ values are very close to those of $\mathrm{A}-*-\mathrm{HF}(\mathrm{A}=\mathrm{He}, \mathrm{Ne}$, and $\mathrm{Ar})$. The $\mathrm{BP}\left(\mathrm{H}_{\text {bay }}-*-\mathrm{C}_{\text {bay }}\right)$ in $\mathbf{6}$ and $\mathbf{9}$ connect the $\mathrm{H}_{\text {bay }}$ and $\mathrm{C}_{\text {bay }}$ atoms. However, they are not located at the nearest positions, as shown in Table 1 and Figure S3 of the Supporting Information. Therefore, the BP $\left(\mathrm{H}_{\mathrm{bay}}-*-\mathrm{C}_{\mathrm{bay}}\right)$ in $\mathbf{6}$ and $\mathbf{9}$ should be analyzed carefully.

One, one, four, four, seven, and eight different types of $\mathrm{C}-*-\mathrm{C}$ interactions are detected for 7-12, respectively. The $\left(\theta, \theta_{p}\right)$ values for $C-*-C$ in $7-12$ are $\left(70.0-72.9^{\circ}, 66.3-94.2^{\circ}\right)$. It appears better to separately examine the values for two groups of $\mathrm{C}_{\text {bay }}-*-\mathrm{C}_{\text {bay }}$ and $\mathrm{C}_{\text {cape }}$ $*-C_{\text {cape }}$. While the $\left(\theta, \theta_{\mathrm{p}}\right)$ values of $\mathrm{C}_{\text {bay }}-*-\mathrm{C}_{\text {bay }}$ in $7-12$ are $\left(71.5-72.9^{\circ}, 79.5-87.8^{\circ}\right)$, the values are $\left(70.0-70.7^{\circ}, 66.3-69.7^{\circ}\right)$ for $C_{\text {cape }}-*-C_{\text {cape }}$. The $\theta$ values for $C_{\text {cape }}-*-C_{\text {cape }}$ are slightly smaller than those of $C_{\text {bay }}-*-C_{\text {bay }}\left(\right.$ by $\left.0.5-2.2^{\circ}\right)$, but the $\theta_{p}$ values for $C_{\text {cape }}-*-C_{\text {cape }}$ are much smaller than those of $C_{\text {bay }}-*-C_{\text {bay }}$ (by 13.2-24.5 ). In this case, $\theta_{\mathrm{p}}<\theta$ for $\mathrm{C}_{\text {cape }}{ }^{-*-}$ $\mathrm{C}_{\text {cape, whereas }} \theta_{\mathrm{p}}>\theta$ for $\mathrm{C}_{\text {bay }}-*-\mathrm{C}_{\text {bay }}$. Interactions with $\theta_{\mathrm{p}}>\theta$ are usually observed, but interactions with $\theta_{\mathrm{p}}<\theta$ are rare.

Interactions with $\theta>\theta_{\mathrm{p}}$ occur under some specific conditions. To examine the behaviour of $\theta$ and $\theta_{\mathrm{p}}$ in $\mathbf{7 - 1 2}$, the $\Delta \theta_{\mathrm{p}}\left(=\theta_{\mathrm{p}}-\theta\right)$ values are plotted versus $\theta_{\mathrm{p}}$ for $\mathrm{C}-*-\mathrm{C}, \mathrm{H}-*-\mathrm{H}$ and $\mathrm{C}-*-\mathrm{H}$ in 3-12. Figure 4 shows this plot. The plot showed a very good correlation for all data $\left(y=0.918 x-64.88: R_{\mathrm{c}}{ }^{2}=0.995\right)$. (A substantial correlation was not found in the plot of $\Delta \theta_{\mathrm{p}}$ versus $\theta$ due to the very small range of $\theta$ ). The two areas for $\mathrm{C}-*-\mathrm{C}$ interactions with $\Delta \theta_{\mathrm{p}}>0$ and $\Delta \theta_{\mathrm{p}}<0$ are clearly illustrated by the green dotted lines in Figure 4 . The $\Delta \theta_{\mathrm{p}}$ values for the interactions are positive if the $\theta_{\mathrm{p}}$ values are larger than $70.7^{\circ}$, whereas $\Delta \theta_{\mathrm{p}}<0$ if $\theta_{\mathrm{p}}<70.7^{\circ}$. Figure 4 clearly shows that $\mathrm{C}_{\text {bay }}-*-\mathrm{C}_{\text {bay }}$ and $\mathrm{C}_{\text {cape }}-*-\mathrm{C}_{\text {cape }}$ in $\mathbf{9 - 1 2}$ belong to the areas where $\Delta \theta_{\mathrm{p}}>0$ and $\Delta \theta_{\mathrm{p}}<0$, respectively.

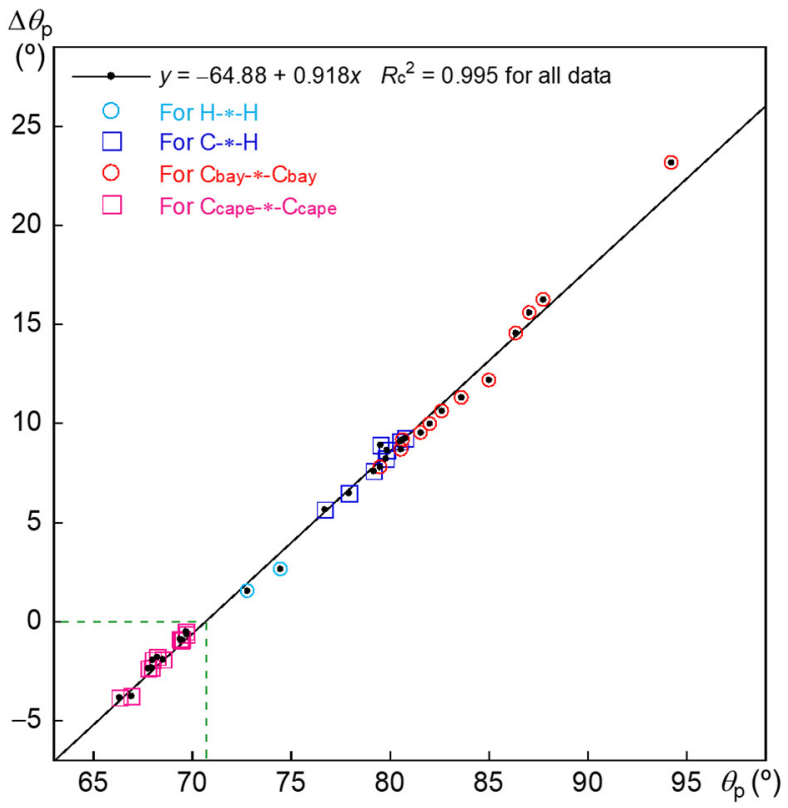

Figure 4. Plot of $\Delta \theta_{\mathrm{p}}$ versus $\theta_{\mathrm{p}}$ for $\mathrm{H}-*-\mathrm{H}, \mathrm{C}-*-\mathrm{H}$, and $\mathrm{C}-*-\mathrm{C}$ in 3-12, evaluated with M06-2X/6$311+G(3 d, p)$, where $\Delta \theta_{p}=\left(\theta_{p}-\theta\right)$.

It seems difficult to clearly explain the results shown in Figure 4; however, our explanation is as follows: The static nature of the interactions described by $\theta$ should be a measure of the strength of the interactions. If so, the steric compression on $\mathrm{C}_{\text {cape }}{ }^{-*-\mathrm{C}_{\text {cape }}}$ 
in 9-12 appears to be similar to that on $C_{\text {bay }}-*-C_{\text {bay }}$ in fully optimized structures. Namely, the $\mathrm{C}_{\text {cape }}-*-\mathrm{C}_{\text {cape }}$ and $\mathrm{C}_{\text {bay }}-*-\mathrm{C}_{\text {bay }}$ interactions in the fully optimized structures of 9-12 would be affected similarly to steric compression, according to the $\theta$ values. On the other hand, the dynamic nature of the interactions is defined by $\theta_{p}$ based on the behaviour of the interactions in the perturbed structures. The $C_{\text {bay }}-*-C_{\text {bay }}$ interactions in the perturbed structures will be affected by steric compression, similar to the usual cases of interactions, whereas the $\mathrm{C}_{\text {cape }}{ }^{*-}-\mathrm{C}_{\text {cape }}$ interactions will be inversely affected compared with the usual cases when measured by the $\theta_{\mathrm{p}}$ values at the BCPs of the interactions.

\subsection{Nature of Each $X-*-Y$ in $\mathbf{6 : 6}$ and $7: 7$}

What is the behaviour of the interactions when the helicenes form concave-type dimers? The behaviour was elucidated, exemplified by $6: 6\left(C_{\mathrm{i}}\right)$ and 7:7 $\left(C_{\mathrm{i}}\right)$ with M06-2X/6$311+G(3 d, p)$. Figure 5 shows molecular graphs of $\mathbf{6 : 6}$ and 7:7. Five and four independent BPs with BCPs were detected in 6:6 and 7:7, respectively, between the components of $\mathrm{H}-*-\mathrm{H}$ and $\mathrm{C}-*-\mathrm{H}$, as well as two independent BPs with BCPs for the intramolecular C-*$\mathrm{H}$ interactions in each component of 6:6 and 7:7. The behaviour of the interactions was also investigated for 7:7 $\left(C_{\mathrm{i}}\right), 8: 8\left(C_{\mathrm{i}}\right)$, and / or 10:10 $\left(C_{\mathrm{i}}\right)$ with M06-2X/6-311+G(2d,p) and LC- $\omega$ PBE $/ 6-311+G(2 d, p)$. The results are collected in Tables S7 and S8 of the Supporting Information. The QTAIM functions were similarly calculated for the intermolecular interactions at the BCPs on the BPs of 6:6 and 7:7 with M06-2X/6-311+G(3d,p).

(a)

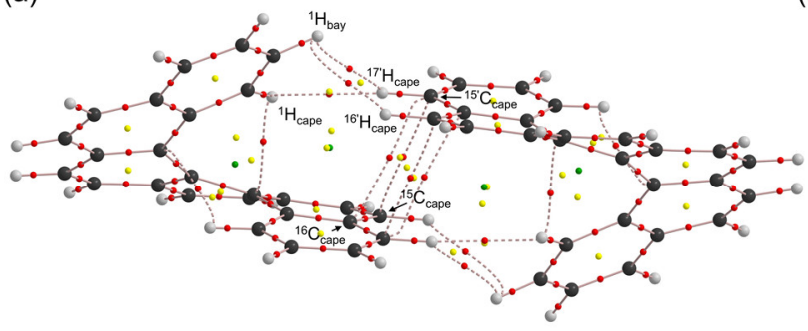

$6: 6\left(C_{\mathrm{i}}\right)$ (b)

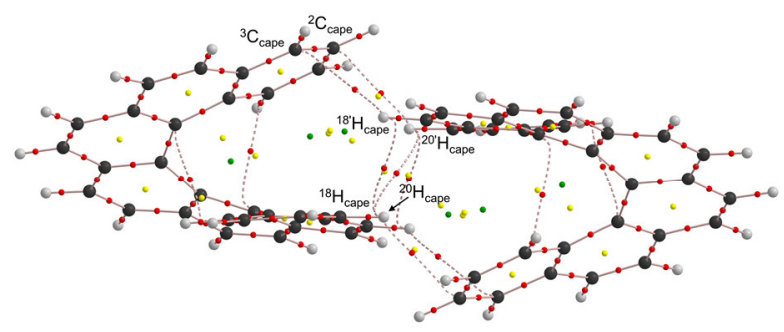

$7: 7\left(C_{\mathrm{i}}\right)$

Figure 5. Molecular graphs for helicene dimers, 6:6 (a) and 7:7 (b), calculated with M06-2X/6$311+\mathrm{G}(3 \mathrm{~d}, \mathrm{p})$, where BPs with BCPs corresponding to intra- and intermolecular noncovalent interactions are detected. The BCPs are denoted by red dots, RCPs (ring critical points) by yellow dots, CCPs (cage critical points) by green dots, and BPs by pink lines. The carbon atoms are in black and the hydrogen atoms are in grey.

Table 2 collects the $\rho_{\mathrm{b}}\left(r_{\mathrm{c}}\right), H_{\mathrm{b}}\left(r_{\mathrm{c}}\right)-V_{\mathrm{b}}\left(r_{\mathrm{c}}\right) / 2$, and $H_{\mathrm{b}}\left(r_{\mathrm{c}}\right)$ values for one of the doubly degenerate interactions due to the $C_{\mathrm{i}}$ symmetry of the optimized structures. Figure 6 shows the plots of $H_{\mathrm{b}}\left(r_{\mathrm{c}}\right)$ versus $H_{\mathrm{b}}\left(r_{\mathrm{c}}\right)-V_{\mathrm{b}}\left(r_{\mathrm{c}}\right) / 2$ for each interaction between the components at 6:6 and 7:7. (The plots for 8:8 and 10:10 are shown in Figure S7 of the Supporting Information, and the data are collected in Table $\mathrm{S} 8$ of the Supporting Information).

The plots were analyzed similarly to the case of 3-12. Table 2 also collects the QTAIMDFA parameters of $(R, \theta)$ and $\left(\theta_{\mathrm{p}}, \kappa_{\mathrm{p}}\right)$ for the intermolecular interactions in question at 6:6 and 7:7, together with the $C_{i i}$ values corresponding to the interactions in question. The $(\theta$, $\theta_{\mathrm{p}}$ ) values for the three $\mathrm{H}-*-\mathrm{H}$ and two $\mathrm{C}-*-\mathrm{C}$ intermolecular independent interactions of $6: 6$ are $\left(70.9-74.3^{\circ}, 74.9-88.1^{\circ}\right)$ and $\left(68.3-69.2^{\circ}, 68.0-70.8^{\circ}\right)$, respectively. The $\left(\theta, \theta_{\mathrm{p}}\right)$ values for the couple of $\mathrm{H}-*-\mathrm{H}$ and two $\mathrm{C}-*-\mathrm{H}$ intermolecular independent interactions at 7:7 are $\left(68.9-70.0^{\circ}, 72.7-75.5^{\circ}\right)$ and $\left(71.4-73.8^{\circ}, 73.2-73.3^{\circ}\right)$, respectively. The $\theta$ and $\theta_{\mathrm{p}}$ values for the intermolecular $\mathrm{H}-*-\mathrm{H}, \mathrm{C}-*-\mathrm{H}$, and $\mathrm{C}-*-\mathrm{C}$ interactions at 6:6 and 7:7 are all less than $90^{\circ}$; therefore, the interactions are all predicted to have a $p$-CS/vdW nature (see Table 2). The interactions appear to be very weak, based on the $\left(\theta, \theta_{\mathrm{p}}\right)$ values. However, $\left(\theta, \theta_{\mathrm{p}}\right)=\left(72.6^{\circ}\right.$, $\left.88.1^{\circ}\right)$ for $6: 6\left({ }^{1} \mathrm{H}_{\text {bay }}-{ }^{-1}-{ }^{\prime} \mathrm{H}_{\text {cape }}\right)$, of which nature seems close to $p-\mathrm{CS} / t-\mathrm{HB}_{\mathrm{nc}}$. 


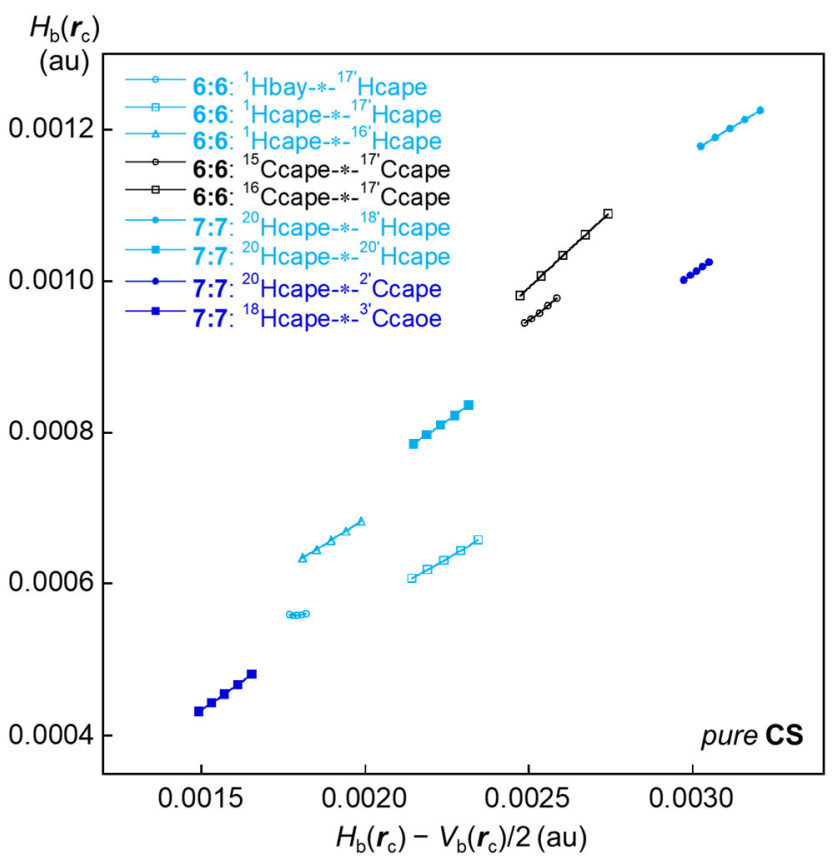

Figure 6. Plots of $H_{\mathrm{b}}\left(r_{\mathrm{c}}\right)$ versus $H_{\mathrm{b}}\left(\boldsymbol{r}_{\mathrm{c}}\right)-V_{\mathrm{b}}\left(\boldsymbol{r}_{\mathrm{c}}\right) / 2$ for $\mathrm{H}-*-\mathrm{H}, \mathrm{C}-*-\mathrm{H}$, and $\mathrm{C}-*-\mathrm{C}$ at 6:6 $\left(C_{\mathrm{i}}\right)$ and 7:7 $\left(C_{\mathrm{i}}\right)$, calculated with M06-2X/6-311+G(3d,p).

In the case of intramolecular interactions, ${ }^{1} \mathrm{H}_{\text {bay }}-{ }^{-}{ }^{5} \mathrm{C}_{\text {bay }}$ and ${ }^{3} \mathrm{C}_{\text {bay }}-*-{ }^{7} \mathrm{H}_{\text {bay }}$ were detected at 6:6. The former was also observed in 6, whereas the latter was newly detected in 6:6. The new appearance of $6\left({ }^{3} \mathrm{C}_{\mathrm{bay}}-{ }_{-}-{ }^{7} \mathrm{H}_{\mathrm{bay}}\right)$ may be due to a structural change at 6:6 relative to 6. Similarly, ${ }^{1} \mathrm{H}_{\text {bay }}-{ }^{*-}{ }^{6} \mathrm{C}_{\text {bay }}$ and ${ }^{3} \mathrm{C}_{\text {bay }}-{ }^{-}{ }^{8} \mathrm{H}_{\text {bay }}$ were detected at 7:7. The former was observed in 7 , while ${ }^{3} \mathrm{C}_{\text {bay }}-{ }_{-}{ }^{8} \mathrm{H}_{\text {bay }}$ in 7:7 appeared in place of ${ }^{2} \mathrm{C}_{\text {bay }}{ }^{-*-}{ }^{7} \mathrm{C}_{\text {bay }}$ in 7 . The change in the optimized structures between 7 and 7:7 would again be responsible for the results. However, clarifying the reason for the appearance/disappearance of BPs is very complex and difficult in helicenes, and it is beyond the scope of this work.

Highly theoretical treatment must be necessary to clarify the reason for the appearance and disappearance of BPs/BCPs. Pendás and coworkers discussed BPs as privileged exchange channels, using the interacting quantum atom (IQA) framework [72]. They have investigated how BPs between an atom A and atoms B in its environment appear to be determined by competition among the $\mathrm{A}-\mathrm{B}$ exchange correlation energies that always contribute to stabilize the A-B interactions. And they have predicted that a BP is found between two atoms by examining a number of archetypal simple systems: (1) there is no other competing atom in its vicinity, so there must be a direct exchange route between them or (2) its $\mathbf{V}_{\mathrm{xc}}$ term is the largest among several possibilities, where $\mathbf{V}_{\mathrm{xc}}$ stands for a quantum-mechanical correction coming from the exchange correlation second-order density [72]. It has also indicated that interaction energies between both atoms cannot be universally used to predict the existence of a BP between them [73]. Moreover, they are not correlated to distances or to the density values at BCPs. On the contrary, the exchange contribution is shown to be an appropriate descriptor [73]. Similarly, theoretical treatments are applied to various interactions, employing QTAIM-defined an atomic interaction line (AIL: Presence or absence), IQA-defined interaction energy and its components, NCI (noncovalent interactions)-defined isosurfaces, and deformation density [74]. The reason for the appearance and disappearance of BPs/BCPs in the helicenes would be rationalized by applying above theory [27].

The $\left(\theta, \theta_{\mathrm{p}}\right)$ values for the intramolecular interactions at 6:6 and 7:7 are $\left(70.8-71.9^{\circ}\right.$, $78.3-80.0^{\circ}$ ). As a result, the interactions are all predicted to have a $p$-CS/vdW nature (see Table 2). The predicted natures of the interactions in $6: 6$ and 7:7 appear to be similar to those in 6 and 7, perhaps due to the very weak nature of both dimers and monomers. 


\section{Basis Set and Level Dependence of the Predicted Natures}

The basis set and level dependence of the predicted natures was investigated, exemplified by 7 and 7:7, to attempt to determine the reason why the optimized structures can easily change. Table 3 shows the QTAIM-DFA parameters of $(R, \theta)$ and $\left(\theta_{\mathrm{p}}, \kappa_{\mathrm{p}}\right)$ and the $C_{i i}$ values, calculated with M06-2X/6-311+G(3d,p), M06-2X/6-311+G(2d,p), and LC$\omega \mathrm{PBE} / 6-311+\mathrm{G}(2 \mathrm{~d}, \mathrm{p})$. Table 3 includes the distances in question as well as some internal vibration(s) $v_{n}$ corresponding to the interactions in question, which are closely related to $\left(\theta_{\mathrm{p}}\right.$ $\left.\kappa_{\mathrm{p}}\right)$. Figure 7 shows the motions of the internal vibrations for $v_{1}$ of 7 and 7:7 calculated with M06-2X/6-311+G(3d,p), M06-2X/6-311+G(2d,p), and LC- $\omega$ PBE/6-311+G(3d,p). (Other motions are shown in Figure $S 9$ of the Supporting Information).

Table 3. QTAIM Functions and QTAIM-DFA Parameters Evaluated for the Fused Benzene-Type Helicene (7) and the Concave-Type Dimer (7:7), Employing the Perturbed Structures Generated with CIV, together with the $\mathrm{X}-*-\mathrm{Y}$ Distances and the Corresponding Internal Vibrations, with the Frequencies Closely Related to the Interactions in Question ${ }^{1,2}$.

\begin{tabular}{|c|c|c|c|c|c|c|c|}
\hline Species & $r(\mathrm{X} \cdots \mathrm{Y})$ & $R$ & $\theta$ & $C_{i i}$ & $\theta_{\mathrm{p}}$ & $\kappa_{\mathrm{p}}$ & $\begin{array}{c}\text { Predicted } \\
\text { Nature }\end{array}$ \\
\hline $\mathbf{X}-*-\mathbf{Y}$ & (Å) & (au) & $\left({ }^{\circ}\right)$ & $\left(\AA ̊ \operatorname{mdyn}^{-1}\right)$ & $\left({ }^{\circ}\right)$ & $\left(a u^{-1}\right)$ & \\
\hline \multicolumn{8}{|c|}{$7\left(\mathrm{M} 06-2 \mathrm{X} / 6-311+\mathrm{G}(3 \mathrm{~d}, \mathrm{p}): v_{1}=43.4 \mathrm{~cm}^{-1}\right)$} \\
\hline${ }^{1} \mathrm{H}_{\text {bay }}-*-{ }^{6} \mathrm{C}_{\text {bay }}$ & 2.5902 & 0.0067 & 71.5 & 5.47 & 77.9 & 187.5 & $p-\mathrm{CS} / \mathrm{vdW}$ \\
\hline${ }^{2} C_{\text {bay }}-*-{ }^{7} C_{\text {bay }}$ & 2.9751 & 0.0054 & 71.9 & 3.33 & 80.6 & 128.2 & $p-\mathrm{CS} / \mathrm{vdW}$ \\
\hline \multicolumn{8}{|c|}{$7\left(\mathrm{M} 06-2 \mathrm{X} / 6-311+\mathrm{G}(2 \mathrm{~d}, \mathrm{p}): v_{1}=46.6 \mathrm{~cm}^{-1}\right)$} \\
\hline${ }^{1} \mathrm{H}_{\text {bay }}{ }^{-*-}{ }^{6} \mathrm{C}_{\text {bay }}$ & 2.5896 & 0.0067 & 70.4 & 5.49 & 81.6 & 39.9 & $p-\mathrm{CS} / \mathrm{vdW}$ \\
\hline${ }^{2} C_{\text {bay }}-*-{ }^{7} C_{\text {bay }}$ & 3.0025 & 0.0054 & 69.9 & 3.06 & 78.7 & 120.2 & $p-\mathrm{CS} / \mathrm{vdW}$ \\
\hline \multicolumn{8}{|c|}{$7\left(\mathrm{LC}-\omega \mathrm{PBE} / 6-311+\mathrm{G}(2 \mathrm{~d}, \mathrm{p}): v_{1}=40.1 \mathrm{~cm}^{-1}\right)^{3,4}$} \\
\hline${ }^{1} \mathrm{H}_{\text {bay }}-*-{ }^{5} \mathrm{C}_{\text {bay }}$ & 2.4681 & 0.0066 & 70.5 & 3.72 & 82.2 & 46.4 & $p-\mathrm{CS} / \mathrm{vdW}$ \\
\hline \multicolumn{8}{|c|}{$7: 7\left(\mathrm{M} 06-2 \mathrm{X} / 6-311+\mathrm{G}(3 \mathrm{~d}, \mathrm{p}): v_{1}=14.0 \mathrm{~cm}^{-1} ; v_{4}=24.2 \mathrm{~cm}^{-1} ; v_{5}=29.3 \mathrm{~cm}^{-1} ; v_{11}=81.2 \mathrm{~cm}^{-1}\right)$} \\
\hline${ }^{20} \mathrm{H}_{\text {cape }}{ }^{-*-}{ }^{18} \mathrm{H}_{\text {cape }}$ & 2.5423 & 0.0033 & 68.9 & 14.61 & 75.5 & 24.6 & $p-\mathrm{CS} / \mathrm{vdW}$ \\
\hline${ }^{20} \mathrm{H}_{\text {cape }^{-*-}{ }^{20} \mathrm{H}_{\text {cape }}}$ & 2.7155 & 0.0024 & 70.0 & 27.90 & 72.7 & 36.5 & $p-\mathrm{CS} / \mathrm{vdW}$ \\
\hline${ }^{20} \mathrm{H}_{\text {cape }}-*-{ }^{\prime} \mathrm{C}_{\text {cape }}$ & 2.6769 & 0.0032 & 71.4 & 10.01 & 73.3 & 125.7 & $p-\mathrm{CS} / \mathrm{vdW}$ \\
\hline${ }^{18} \mathrm{H}_{\text {cape }^{-*-}{ }^{3} \mathrm{C}_{\text {cape }}}$ & 2.9640 & 0.0016 & 73.8 & 17.36 & 73.2 & 181.8 & $p-\mathrm{CS} / \mathrm{vdW}$ \\
\hline \multicolumn{8}{|c|}{$7: 7\left(\mathrm{M} 06-2 \mathrm{X} / 6-311+\mathrm{G}(2 \mathrm{~d}, \mathrm{p}): v_{1}=13.0 \mathrm{~cm}^{-1} ; v_{4}=22.1 \mathrm{~cm}^{-1} ; v_{5}=27.3 \mathrm{~cm}^{-1} ; v_{11}=78.6 \mathrm{~cm}^{-1}\right)$} \\
\hline${ }^{20} \mathrm{H}_{\text {cape }}{ }^{-*-}{ }^{18^{\prime}} \mathrm{H}_{\text {cape }}$ & 2.5643 & 0.0032 & 67.9 & 16.63 & 75.2 & 60.1 & $p-\mathrm{CS} / \mathrm{vdW}$ \\
\hline${ }^{20} \mathrm{H}_{\text {cape }}{ }^{*-2}{ }^{20} \mathrm{H}_{\text {cape }}$ & 2.7287 & 0.0024 & 68.6 & 29.20 & 71.9 & 42.2 & $p-\mathrm{CS} / \mathrm{vdW}$ \\
\hline${ }^{20} \mathrm{H}_{\text {cape }}{ }^{-*-}{ }^{2} \mathrm{C}_{\text {cape }}$ & 2.6881 & 0.0031 & 70.2 & 11.44 & 69.4 & 12.4 & $p-\mathrm{CS} / \mathrm{vdW}$ \\
\hline${ }^{18} \mathrm{H}_{\text {cape }{ }^{-*-}{ }^{3}} \mathrm{C}_{\text {cape }}$ & 2.9857 & 0.0016 & 73.0 & 31.43 & 73.2 & 181.9 & $p-\mathrm{CS} / \mathrm{vdW}$ \\
\hline \multicolumn{8}{|c|}{ 7:7 (LC- $\omega$ PBE $\left./ 6-311+G(2 d, p): v_{1}=2.1 \mathrm{~cm}^{-1} ; v_{5}=15.8 \mathrm{~cm}^{-1} ; v_{6}=28.8 \mathrm{~cm}^{-1} ; v_{8}=48.2 \mathrm{~cm}^{-1}\right)^{5,6}$} \\
\hline${ }^{20} \mathrm{C}_{\text {cape }}{ }^{-*-}{ }^{18} \mathrm{H}_{\text {cape }}$ & 3.2357 & 0.0015 & 63.8 & 65.63 & 67.4 & 40.4 & $p$-CS/vdW \\
\hline${ }^{20} \mathrm{H}_{\text {cape }}{ }^{*-}{ }^{20} \mathrm{H}_{\text {cape }}$ & 3.0148 & 0.0014 & 63.6 & 96.42 & 66.9 & 90.7 & $p-\mathrm{CS} / \mathrm{vdW}$ \\
\hline${ }^{20} \mathrm{H}_{\text {cape }}-*-{ }^{\prime} \mathrm{C}_{\text {cape }}$ & 3.0656 & 0.0014 & 67.2 & 52.66 & 70.0 & 10.9 & $p-\mathrm{CS} / \mathrm{vdW}$ \\
\hline${ }^{18} \mathrm{H}_{\text {cape }^{-*-}{ }^{3}} \mathrm{C}_{\text {cape }}$ & 3.6594 & 0.0005 & 62.9 & 73.99 & 73.9 & 394.0 & $p$-CS/vdW \\
\hline
\end{tabular}

${ }^{1}$ See footnotes of Table 1 for the QTAIM-DFA parameters and $C_{i i} .{ }^{2}$ The motions of the internal vibrations are shown in Figure 7 and Figure S9 of the Supporting Information. ${ }^{3}$ BPs and BCPs were not detected for ${ }^{1} \mathrm{H}_{\text {bay }}-*-{ }^{6} \mathrm{C}_{\text {bay }}$ and ${ }^{2} \mathrm{C}_{\text {bay }}-*-{ }^{7} \mathrm{C}_{\text {bay }} \cdot{ }^{4} r\left({ }^{1} \mathrm{H}_{\text {bay }}-*-{ }^{6} \mathrm{C}_{\text {bay }}\right)=2.5609 \AA$ and $r\left({ }^{2} \mathrm{C}_{\text {bay }}-*-{ }^{7} \mathrm{C}_{\text {bay }}\right)=3.2265 \AA .{ }^{5} \mathrm{BPs}$ and BCPs were not detected for ${ }^{20} \mathrm{H}_{\text {cape }}{ }^{*-1}{ }^{18} \mathrm{H}_{\text {cape }} \cdot{ }^{6} r\left({ }^{20} \mathrm{H}_{\text {cape }}-*-18^{\prime} \mathrm{H}_{\text {cape }}\right)=2.9473 \AA$. 
(a)

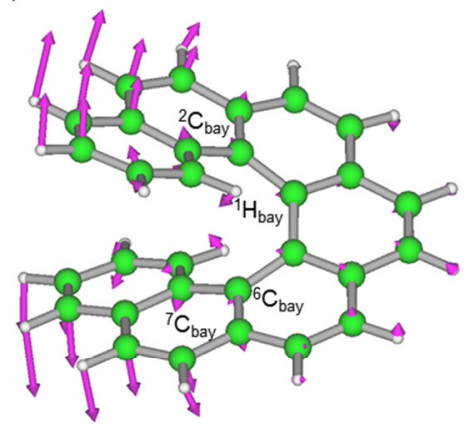

$v_{1}: 48.4 \mathrm{~cm}^{-1}$ (b)

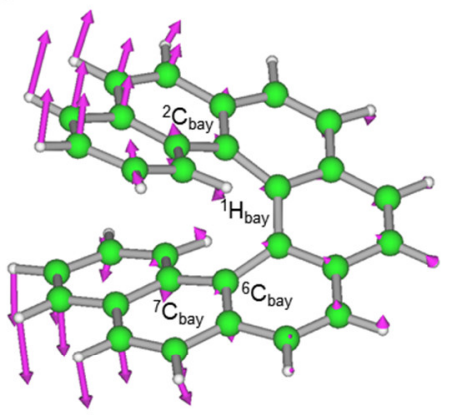

$v_{1}: 46.6 \mathrm{~cm}^{-1}$ (c)

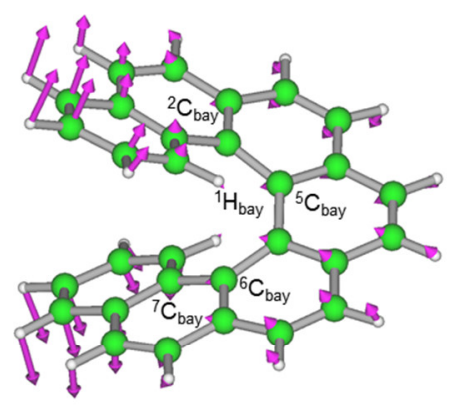

$v_{1}: 40.1 \mathrm{~cm}^{-1}$ (d)

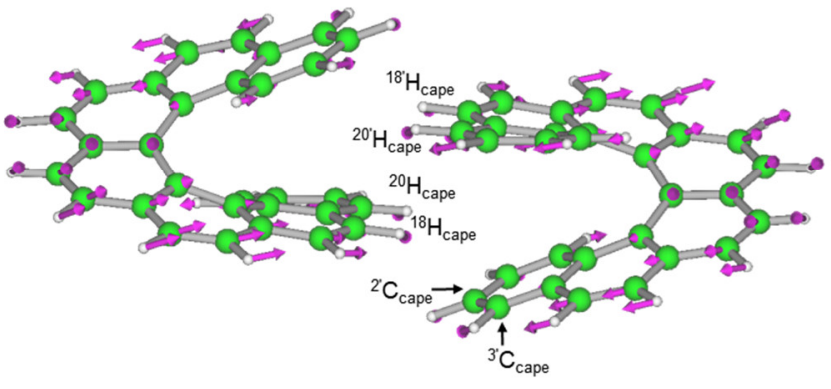

$v_{1}: 14.0 \mathrm{~cm}^{-1}$

(e)

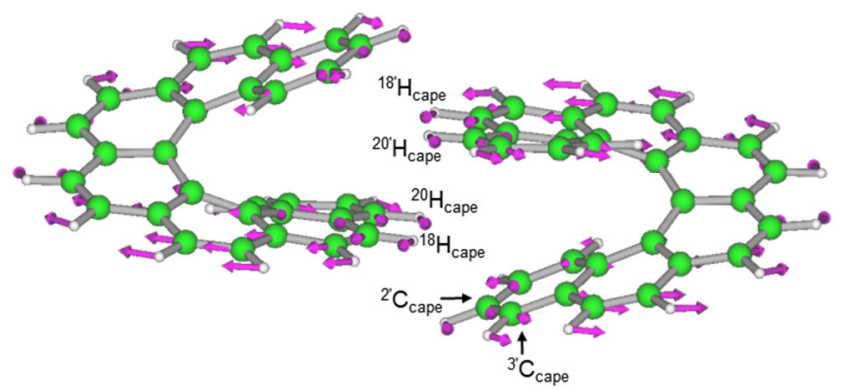

$v_{1}: 13.0 \mathrm{~cm}^{-1}$

(f)

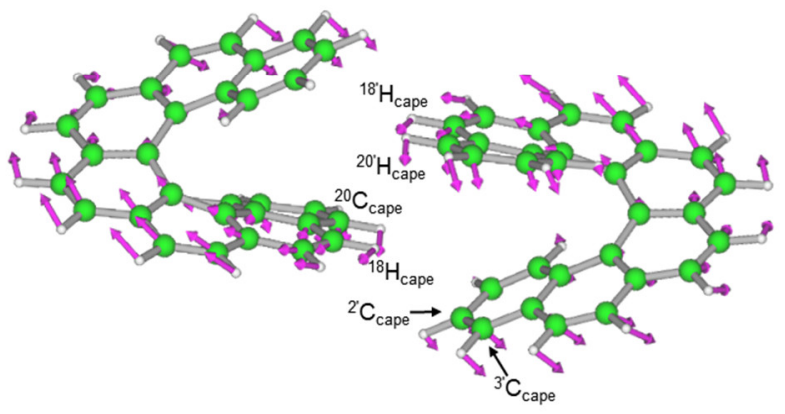

$v_{1}: 2.1 \mathrm{~cm}^{-1}$

Figure 7. The internal vibrational motions of $v_{1}$ for $7\left(C_{2}\right)$ and 7:7 $\left(C_{\mathrm{i}}\right)$. (a) For $7\left(C_{2}\right)$ calculated with M06-2X/6-311+G(3d,p); (b) for $7\left(C_{2}\right)$ calculated with M06-2X/6-311+G(2d,p); (c) for $7\left(C_{2}\right)$ calculated with LC- $\omega$ PBE/6-311+G(2d,p); (d) for 7:7 $\left(C_{\mathrm{i}}\right)$ calculated with M06-2X/6-311+G(3d,p); (e) for 7:7 $\left(C_{\mathrm{i}}\right)$ calculated with M06-2X/6-311+G(2d,p); (f) for 7:7 $\left(C_{\mathrm{i}}\right)$ calculated with LC- $\omega$ PBE/6-311+G(2d,p).

The calculated $r\left({ }^{1} \mathrm{H}_{\text {bay }} \cdot{ }^{6} \mathrm{C}_{\text {bay }}\right)$ and $r\left({ }^{2} \mathrm{C}_{\text {bay }} \cdot{ }^{7} \mathrm{C}_{\text {bay }}\right)$ distances were $2.590 \AA$ and $2.975 \AA$, respectively, for 7 , when calculated with $M 06-2 X / 6-311+(3 d, p)$, while the values were $2.590 \AA$ and $3.003 \AA$, respectively, when calculated with M06-2X/6-311+(2d,p). The differences are less than $0.001 \AA$ for $r\left({ }^{1} \mathrm{H}_{\text {bay }} \cdot{ }^{6} \mathrm{C}_{\text {bay }}\right)$ and $0.028 \AA$ for $r\left({ }^{2} \mathrm{C}_{\text {bay }} \cdot{ }^{7} \mathrm{C}_{\text {bay }}\right)$. The results show that the structure of 7 optimized with $M 06-2 X / 6-311+(2 d, p)$ appears to be nearly identical to that optimized with M06-2X/6-311+(3d,p). On the other hand, the $r\left({ }^{1} \mathrm{H}_{\text {bay }} \cdot{ }^{6} \mathrm{C}_{\text {bay }}\right)$ and $r\left({ }^{2} \mathrm{C}_{\text {bay }} \cdot{ }^{7} \mathrm{C}_{\text {bay }}\right)$ of 7 were $2.561 \AA$ and $3.227 \AA$, respectively, if calculated with LC- $\omega$ PBE/6-311+(2d,p). The difference was $-0.029 \AA$ for the former but $0.224 \AA$ for the latter relative to the corresponding values calculated with M06-2X/6-311+(2d,p). The structure of 7 optimized with LC- $\omega$ PBE /6-311+(2d,p) appears to be (very) different from that optimized with M06-2X/6-311+(2d,p), especially around $r\left({ }^{2} \mathrm{C}_{\text {bay }} \cdot{ }^{7} \mathrm{C}_{\text {bay }}\right)$. In the case of ${ }^{1} \mathrm{H}_{\text {bay }} \cdot{ }^{5} \mathrm{C}_{\text {bay }}$, the distance was optimized to be $2.468 \AA$ with LC-wPBE/6-311+(2d,p), 
which is shorter than the $r\left({ }^{1} \mathrm{H}_{\text {bay }}{ }^{6}{ }^{6} \mathrm{C}_{\text {bay }}\right)$ distance optimized with M06-2X/6-311+(2d,p) $\left(2.590 \AA\right.$ ) by $0.122 \AA$. BPs (with BCPs) were detected for ${ }^{1} \mathrm{H}_{\text {bay }}{ }^{-*}{ }^{6} \mathrm{C}_{\text {bay }}$ and ${ }^{2} \mathrm{C}_{\text {bay }}{ }^{*-}-{ }^{7} \mathrm{C}_{\text {bay }}$ in 7 if calculated with M06-2X/6-311+(3d,p) and M06-2X/6-311+(2d,p), while a BP was detected for ${ }^{1} \mathrm{H}_{\text {bay }}{ }^{*-}{ }^{5} \mathrm{C}_{\text {bay }}$ if calculated with LC- $\omega$ PBE $/ 6-311+(2 \mathrm{~d}, \mathrm{p})$. The ${ }^{2} \mathrm{C}_{\text {bay }}{ }^{-*-}{ }^{7} \mathrm{C}_{\text {bay }}$ and ${ }^{1} \mathrm{H}_{\text {bay }}-{ }^{-}{ }^{5} \mathrm{C}_{\text {bay }}$ distances in 7 , optimized with LC- $\omega$ PBE $/ 6-311+(2 \mathrm{~d}, \mathrm{p})$, were (much) longer and shorter than those optimized with M06-2X/6-311+(2d,p), respectively.

The differences in the optimized distances appear to be the main factor for the appearance/disappearance of the BPs, although predicting the appearance/disappearance of the $\mathrm{BPs}$ is very difficult and complex. Despite such different results, the motion of $v_{1}$ appears to be very similar when calculated at both the M06-2X and LC- $\omega$ PBE levels, indicating that $v_{1}$ is a good measure for imaging the dynamic nature of the $\pi \cdots \pi$ interactions in 7 among the internal vibrations. Small differences in the dynamic nature of the interactions predicted at both the M06-2X and LC- $\omega$ PBE levels result from the (very) similar motion of $v_{1}$. The magnitudes of the displacements in the cape area seem (much) larger than those in the bay area in $v_{1}$. This will be instructive if the relationship is clarified for that between the magnitudes of the displacements and the $\Delta \theta_{p}$ values. This issue will be investigated in a future work. The very low energy of $v_{1}$ in 7 suggests the basis set and level dependence can easily change the optimized structure.

In the case of $7: 7$, the $r\left({ }^{20} \mathrm{H}_{\text {cape }} \cdots{ }^{18^{\prime}} \mathrm{H}_{\text {cape }}\right), r\left({ }^{20} \mathrm{H}_{\text {cape }} \cdots{ }^{20} \mathrm{H}_{\text {bay }}\right), r\left({ }^{20} \mathrm{H}_{\text {cape }} \cdots{ }^{\prime} \mathrm{C}_{\text {cape }}\right)$, and $r\left({ }^{8} \mathrm{H}_{\text {cape }} \cdot{ }^{3}{ }^{\prime} \mathrm{C}_{\text {cape }}\right)$ distances were $2.543 \AA, 2.716 \AA, 2.677 \AA$, and $2.964 \AA$, respectively, when calculated with M06-2X/6-311+(3d,p), while the values were $2.564 \AA, 2.729 \AA, 2.688 \AA$, and $2.986 \AA$, respectively, when calculated with M06-2X/6-311+(2d,p). The differences are $0.011-0.022 \AA$, which are less than approximately $0.02 \AA$. The results show that the optimized structures of 7:7 are very similar with both M06-2X/6-311+(3d,p) and M06-2X/6$311+(2 \mathrm{~d}, \mathrm{p})$. On the other hand, the distances are optimized to be $2.947 \AA, 3.015 \AA, 3.066 \AA$, and $3.659 \AA$ with LC- $\omega$ PBE $/ 6-311+(2 \mathrm{~d}, \mathrm{p})$. The differences with the corresponding values of M06-2X/6-311+(2d,p) are 0.286-0.674 $\AA$. Namely, the structure of 7:7 optimized with LC- $\omega \mathrm{PBE} / 6-311+(2 \mathrm{~d}, \mathrm{p})$ appears to be very different from that optimized with M06-2X/6$311+(2 \mathrm{~d}, \mathrm{p})$, similar to the case of 7 .

The ${ }^{20} \mathrm{C}_{\text {cape }}{ }^{-*-}{ }^{18^{\prime}} \mathrm{H}_{\text {cape }}$ distance was optimized to be $3.236 \AA$, which is longer than $r\left({ }^{20} \mathrm{H}_{\text {cape }} \cdots{ }^{18^{\prime}} \mathrm{H}_{\text {cape }}\right)(2.947 \AA)$ by $0.288 \AA$ with LC- $\omega P B E / 6-311+(2 \mathrm{~d}, \mathrm{p})$. However, a BP was detected for ${ }^{20} \mathrm{C}_{\text {cape }}{ }^{-*-1}{ }^{1} \mathrm{H}_{\text {cape }}$ but not for ${ }^{20} \mathrm{H}_{\text {cape }}{ }^{*-1}{ }^{18} \mathrm{H}_{\text {cape }}$. The difference in the atomic size between $\mathrm{C}$ and $\mathrm{H}$, such as the van der Waals radii, may be responsible for the predicted results, in this case. The ${ }^{20} \mathrm{C}_{\text {cape }{ }^{*-}-}{ }^{18^{\prime}} \mathrm{H}_{\text {cape }},{ }^{20} \mathrm{H}_{\text {cape }}{ }^{-*-}{ }^{20} \mathrm{H}_{\text {bay }},{ }^{20} \mathrm{H}_{\text {cape-*- }}$ ${ }^{2} \mathrm{C}_{\text {cape, }}$ and ${ }^{8} \mathrm{H}_{\text {cape }}-{ }^{-}-{ }^{3} \mathrm{C}_{\text {cape }}$ distances at $7: 7$, optimized with LC- $\omega \mathrm{PBE} / 6-311+(2 \mathrm{~d}, \mathrm{p})$, were much longer than the corresponding distances, optimized with M06-2X/6-311+(2d,p). BPs were detected for ${ }^{20} \mathrm{H}_{\text {cape-*- }}{ }^{18^{\prime}} \mathrm{H}_{\text {cape }},{ }^{20} \mathrm{H}_{\text {cape }}{ }^{-*-20^{\prime}} \mathrm{H}_{\text {bay }},{ }^{20} \mathrm{H}_{\text {cape }}-{ }^{-2}{ }^{\prime} \mathrm{C}_{\text {cape }}$, and ${ }^{18} \mathrm{H}_{\text {cape }}{ }^{-*-}$ ${ }^{3} \mathrm{C}_{\text {cape }}$ when calculated with M06-2X/6-311+(2d,p), while they were detected for ${ }^{20} \mathrm{C}_{\text {cape }}{ }^{-}$ ${ }_{*-}{ }^{18^{\prime}} \mathrm{H}_{\text {cape }}{ }^{20} \mathrm{H}_{\text {cape }}-*-2{ }^{\prime} \mathrm{H}_{\text {bay }},{ }^{20} \mathrm{H}_{\text {cape }-*-2}{ }^{\prime} \mathrm{C}_{\text {cape }}$, and ${ }^{8} \mathrm{H}_{\text {cape }}-*-{ }^{3} \mathrm{C}_{\text {cape }}$ when calculated with $\mathrm{LC}-\omega \mathrm{PBE} / 6-311+(2 \mathrm{~d}, \mathrm{p})$. The differences in the optimized distances appear to be the main factor for the appearance/disappearance of the BPs, similar to the case of 7 .

Table 3 contains the $v_{1}$ values for 7 and 7:7, calculated with M06-2X/6-311+(3d,p), M06-2X/6-311+(2d,p), and LC- $\omega$ PBE/6-311+(2d,p). Table 3 also contains some vibrations closely related to the interactions in question (corresponding to the perturbed structures) at $7: 7$, where most candidates were found to be less than $v_{n}$ of $v_{20}$. The $v_{1}$ values for 7 were $48.4 \mathrm{~cm}^{-1}, 46.6 \mathrm{~cm}^{-1}$, and $40.2 \mathrm{~cm}^{-1}$ when calculated with the three methods, respectively. The $v_{1}$ motion of 7 appears to be very similar when calculated with the three methods. In the case of 7:7, the frequencies of $v_{1}$ calculated with M06-2X/6-311+G(3d,p) and M06-2X/6$311+G(2 d, p)$ were $14.0 \mathrm{~cm}^{-1}$ and $13.1 \mathrm{~cm}^{-1}$, respectively, while the value calculated with LC- $\omega$ PBE was $2.1 \mathrm{~cm}^{-1}$. Very large differences are predicted for $v_{1}$ at $7: 7$ when calculated at the M06-2X and LC- $\omega$ PBE levels. The $v_{1}$ value with the motion should correspond to the strength of the interactions in the direction of the perturbed structures.

The $\left(\theta, \theta_{\mathrm{p}}\right)$ values of $7: 7$ are $\left(67.9-73.0^{\circ}, 69.4-75.2^{\circ}\right)$ and $\left(62.9-67.2^{\circ}, 67.4-73.9^{\circ}\right)$ with M06-2X/6-311+(2d,p) and LC- $\omega$ PBE/6-311+(2d,p), respectively. The differences seem large 
relative to the case of 7 , with $\left(\theta, \theta_{\mathrm{p}}\right)$ values of $\left(70.4^{\circ}, 81.6^{\circ}\right)$ and $\left(70.5^{\circ}, 82.2^{\circ}\right)$ when calculated with M06-2X/6-311+(2d,p) and LC- $\omega$ PBE/6-311+(2d,p), respectively, although $7\left({ }^{1} \mathrm{H}_{\mathrm{bay}^{-*}}\right.$ $\left.{ }^{6} \mathrm{C}_{\text {bay }}\right)$ was detected with M06-2X/6-311+(2d,p) and $7\left({ }^{1} \mathrm{H}_{\text {bay }}{ }^{-*-}{ }^{5} \mathrm{C}_{\text {bay }}\right)$ was detected with LC- $\omega$ PBE / 6-311+(2d,p). The (optimized) structures of 7:7 would be affected more easily by surroundings containing the calculation methods than the case of 7 . The basis set and level dependence of the interactions in 7 and 7:7 can help us to better understand the interactions in helicenes.

The unit of $C_{i i}\left[\AA\right.$ mdyn $\left.^{-1}\right]$ is the inverse of that of the force constant, which corresponds to the frequency. Therefore, the strengths of the interactions should be roughly inversely proportional to the $C_{i i}$ values. As shown in Table 3 , the $C_{i i}$ values for the $\pi \cdots \pi$ interactions of 7 are 3.1-5.5 $\AA$ mdyn $^{-1}$ for $\mathrm{H}_{\text {bay }}-*-\mathrm{C}_{\text {bay }}$ and $\mathrm{C}_{\text {bay }}-*-\mathrm{C}_{\text {bay }}$ with the three methods. The values for the $\pi \cdots \pi$ interactions of 7:7 are 10.0-27.9, 11.4-31.4, and 52.7-96.4 $\AA$ mdyn $^{-1}$ for $\mathrm{H}_{\text {cape }}-*-\mathrm{H}_{\text {cape }}$ and $\mathrm{H}_{\text {cape }}-*-\mathrm{C}_{\text {cape }}$ when calculated with M06-2X/6-311+(3d,p), M06-2X/6-311+(2d,p), and LC- $\omega$ PBE/6-311+(2d,p), respectively. This consideration explains the above results.

\section{Conclusions}

It is challenging to clarify the natures of $\pi \cdots \pi$ interactions in helicenes since the interactions are factors that control the fine details of structures and are expected to give rise to specific functionalities for the species. The repulsive interactions between the benzene rings in helicenes must be very strong; therefore, the $\pi \cdots \pi$ interactions would be considered strong. The $\pi \cdots \pi$ interactions in the helicenes are described by the $\mathrm{H}-*-\mathrm{H}$, $\mathrm{C}-*-\mathrm{H}$, and $\mathrm{C}-*-\mathrm{C}$ forms with BPs and BCPs. The $\pi \cdots \pi$ interactions in helicenes 1-12, as well as in dimers 6:6 and 7:7, were analyzed with QTAIM-DFA after clarifying the structural features and the energy profile. $H_{\mathrm{b}}\left(\boldsymbol{r}_{\mathrm{c}}\right)$ was plotted versus $H_{\mathrm{b}}\left(\boldsymbol{r}_{\mathrm{c}}\right)-V_{\mathrm{b}}\left(\boldsymbol{r}_{\mathrm{c}}\right) / 2$, and the data from the fully optimized structures and the perturbed structures around the fully optimized structures were used in QTAIM-DFA. Data from the fully optimized structures in the plots correspond to the static nature of the interactions, which are analyzed using polar coordinate $(R, \theta)$ representation. Data from both the perturbed and fully optimized structures are expressed by $\left(\theta_{\mathrm{p}}, \kappa_{\mathrm{p}}\right)$, where $\theta_{\mathrm{p}}$ corresponds to the tangent line and $\kappa_{\mathrm{p}}$ is the curvature of the plot. The concept of the dynamic nature of the interactions was proposed based on $\left(\theta_{\mathrm{p}}, \kappa_{\mathrm{p}}\right)$.

The interactions were analyzed by dividing the $C$ atoms of 3-12 into $C_{\text {bay }}$ and $C_{\text {cape }}$ and the $\mathrm{H}$ atoms into $\mathrm{H}_{\text {bay }}$ and $\mathrm{H}_{\text {cape }}$. While both $\mathrm{C}_{\text {bay }}$ and $\mathrm{C}_{\text {cape }}$ atoms of 3-12 take part in the interactions, only $\mathrm{H}_{\text {bay }}$ atoms participate as BPs. The $\theta$ and $\theta_{\mathrm{p}}$ values for $\mathrm{H}-*-\mathrm{H}$, $\mathrm{C}-*-\mathrm{H}$, and $\mathrm{C}-*-\mathrm{C}$ of 3-12 are all less than $90^{\circ}$, except for $\mathbf{1 0}\left({ }^{2} \mathrm{C}_{\text {bay }}{ }^{-*-}{ }^{7} \mathrm{C}_{\text {bay }}\right)$, where $(\theta$, $\left.\theta_{\mathrm{p}}\right)=\left(70.5^{\circ}, 94.2^{\circ}\right)$. Therefore, the $\mathrm{H}-*-\mathrm{H}, \mathrm{C}-*-\mathrm{H}$, and $\mathrm{C}-*-\mathrm{C}$ interactions of $\mathbf{3}-\mathbf{1 2}$ are all predicted to have a $p$-CS/vdW nature, except for $10\left({ }^{2} \mathrm{C}_{\mathrm{bay}}-*-{ }^{7} \mathrm{C}_{\mathrm{bay}}\right)$, which is predicted to have a $p-\mathrm{CS} / t-\mathrm{HB}_{\mathrm{nc}}$ nature. While the $\left(\theta, \theta_{\mathrm{p}}\right)$ values of $\mathrm{C}_{\mathrm{bay}}-*-\mathrm{C}_{\mathrm{bay}}$ in 7-12 are (71.5$\left.72.9^{\circ}, 79.5-87.8^{\circ}\right)$, the values are $\left(70.0-70.7^{\circ}, 66.3-69.7^{\circ}\right)$ for $C_{\text {cape }}-*-C_{\text {cape }}$. The $\theta$ values for $\mathrm{C}_{\text {cape }}{ }^{*-} \mathrm{C}_{\text {cape }}$ are slightly smaller than those of $\mathrm{C}_{\text {bay }}-*-\mathrm{C}_{\text {bay }}$ (by $0.5-2.2^{\circ}$ ), but the $\theta_{\mathrm{p}}$ values for $C_{\text {cape }}-*-C_{\text {cape }}$ are much smaller than those of $C_{\text {bay }}-*-C_{\text {bay }}$ (by 13.2-24.5 $)$. In this case, $\theta<\theta_{\mathrm{p}}$ for $\mathrm{C}_{\mathrm{bay}}-*-\mathrm{C}_{\mathrm{bay}}$, whereas $\theta>\theta_{\mathrm{p}}$ for $\mathrm{C}_{\text {cape }}-*-\mathrm{C}_{\text {cape }}$. Interactions with $\theta<\theta_{\mathrm{p}}$ are usually observed, whereas interactions with $\theta>\theta_{\mathrm{p}}$ are rare.

The $\mathrm{H}-*-\mathrm{H}, \mathrm{C}-*-\mathrm{H}$, and $\mathrm{C}-*-\mathrm{C}$ interactions of dimers $6: 6$ and 7:7 were similarly analyzed. The interactions were predicted to have a $p$-CS/vdW nature, although $6: 6\left({ }^{1} \mathrm{H}_{\mathrm{bay}^{-*}-}\right.$ $\left.{ }^{17^{\prime}} \mathrm{H}_{\text {cape }}\right)$ has a nature close to $p$-CS $/ t-\mathrm{HB}_{\mathrm{nc}}$, since $\left(\theta, \theta_{\mathrm{p}}\right)=\left(72.6^{\circ}, 88.1^{\circ}\right)$. The interactions at 3-12 and 6:6 and 7:7 were predicted to be much weaker than expected. The very low energy of $v_{1}$ of 7:7 supports the very weak nature predicted for interactions and the easy dependence of the levels on the nature of the interactions. The strength of the interactions can also be estimated by the $C_{i i}{ }^{-1}$ values. Detecting the interactions and predicting the nature of helicenes will provide a solid basis for investigating and applying the interactions in helicenes. 
Supplementary Materials: The following are available online at https:/ / www.mdpi.com/article/ 10.3390/nano12030321/s1. Table S1: The observed and calculated C $\cdots C$ length $\left(r_{\text {obsd }}\right.$ and $r_{\text {calcd }}$, respectively), which are located in the bay area for 3-5 and the bay and cape area between adjacent aromatic rings for 6-12, together with the differences, $\Delta r_{\text {calcd }}\left(=r_{\text {calcd:XY }}-r_{\text {obsd:XY }}\right)$ in each C $\cdots C$ for 312 , elucidated with various methods. Table $S 2$ : The total energy $E_{\mathrm{ES}}$ and zero-point energy $E_{\mathrm{ZP}}$ values for $n ; n_{\mathrm{p}}$, where $n=1$ to 12 , along with the $\Delta E_{\mathrm{ES}}$ and $\Delta E_{\mathrm{ZP}}\left(n ; n_{\mathrm{p}}\right)$ values, evaluated with M06-2X/6$311+\mathrm{G}(3 \mathrm{~d}, \mathrm{p})$. Table S3: The HOMA indices for $[n]$ acenes, $[n]$ phenacenes, and $[n]$ helicenes, evaluated with M06-2X/6-311+G(3d,p). Table S4: The observed and calculated X-*-Y lengths $\left(R_{\mathrm{obsd}} \mathrm{XY}\right.$ and $R_{\text {calcd:XY, }}$, respectively; $\mathrm{X}, \mathrm{Y}=\mathrm{C}$ and $\left.\mathrm{H}\right)$ and the length of the bond paths $\left(r_{\mathrm{BP}: \mathrm{XY}}\right)$ and the corresponding straight-line distances $\left(R_{\mathrm{SL}: \mathrm{XY}}\right)$, together with the differences, $\Delta R_{\text {calcd:XY }}\left(=R_{\text {calcd:XY }}-R_{\mathrm{obsd}: \mathrm{XY}}\right)$ in each $\mathrm{X}-*-\mathrm{Y}$ for 3-12, 6:6 and 7:7, evaluated with M06-2X/6-311+G(3d,p), where $R_{\mathrm{SL}: X Y}=R_{\text {calcd:XY, }}$ together with 8:8 and 10:10, calculated with M06-2X/6-311+G(2d,p). Table S5: QTAIM functions and QTAIM-DFA parameters for the fused benzene-type helicenes of monomers (3-12 $\left.\left(C_{2}\right)\right)$, together with the nature of each noncovalent interaction, elucidated with M06-2X/6-311+G(2d,p). Table S6: QTAIM functions and QTAIM-DFA parameters for the fused benzene-type helicenes of monomers (3-12 $\left(C_{2}\right)$ ), along with the nature of each noncovalent interaction, elucidated with LC- $\omega$ PBE/6$311+\mathrm{G}(2 \mathrm{~d}, \mathrm{p})$. Table S7: The $E_{\mathrm{ES}}(\mathrm{au}), \Delta E_{\mathrm{ES}}\left(\mathrm{kJ} \mathrm{mol}^{-1}\right)$, and $\Delta E_{\mathrm{ZP}}\left(\mathrm{kJ} \mathrm{mol}^{-1}\right)$ values for 6:6-8:8 and 10:10, evaluated with various methods. Table S8: QTAIM functions and QTAIM-DFA parameters for the concave-type dimer of helicenes $\left(8: 8-10: 10\left(C_{\mathrm{i}}\right)\right)$, together with the nature of each noncovalent interaction, elucidated with M06-2X/6-311+G(2d,p). Figure S1: Plots of $\Delta E_{\mathrm{ZP}}(n)$ versus $\Delta E_{\mathrm{ES}}(n)$, calculated with M06-2X/6-311+G(3d,p). Figure S2: Plots of HOMA indices for $[n]$ acenes $(n=4-12)$ at closed-shell singlet state, $[n]$ acenes $(n=7-12)$ at open-shell singlet state, and $[n]$ phenacenes $(n=4-12)$ versus those for $[n]$ helicenes $(n=4-12)$, calculated with MP2/6-311+G(3d,p). Figure S3: Molecular graphs for 3-6, 8, and 10 calculated with M06-2X/6-311+G(3d,p). Figure S4: Plots of $r_{\mathrm{BP}}$ versus $R_{\mathrm{SL}}$ for $\mathrm{H}_{\text {bay }}-*-\mathrm{H}_{\text {bay }}, \mathrm{C}_{\text {bay }}-*-\mathrm{H}_{\text {bay }}, \mathrm{C}_{\text {bay }}-*-\mathrm{C}_{\text {bay }}$, and $\mathrm{C}_{\text {cape }}-*-\mathrm{C}_{\text {cape }}$ in 3-12, calculated with M06-2X/6$311+\mathrm{G}(3 \mathrm{~d}, \mathrm{p})$. Figure S5: Plots of $H_{\mathrm{b}}\left(\boldsymbol{r}_{\mathrm{c}}\right)$ versus $H_{\mathrm{b}}\left(\boldsymbol{r}_{\mathrm{c}}\right)-V_{\mathrm{b}}\left(\boldsymbol{r}_{\mathrm{c}}\right) / 2$ for $\mathrm{H}-*-\mathrm{H}, \mathrm{C}-*-\mathrm{H}$, and C-*-C for 7, 9 , and 11. Figure S6: Molecular graphs for 8:8 $\left(C_{\mathrm{i}}\right)$ and 10:10 $\left(C_{\mathrm{i}}\right)$ calculated with M06-2X/6-311+G(2d,p). Figure S7: Plots of $H_{\mathrm{b}}\left(r_{\mathrm{c}}\right)$ versus $H_{\mathrm{b}}\left(r_{\mathrm{c}}\right)-V_{\mathrm{b}}\left(r_{\mathrm{c}}\right) / 2$ for $\mathrm{H}-*-\mathrm{H}, \mathrm{C}-*-\mathrm{H}$, and $\mathrm{C}-*-\mathrm{C}$ for 8:8 and 10:10. Figure S8: The internal vibration motions of $v_{n}$ for 7:7 $\left(C_{i}\right)$ from the top view. Figure S9: The internal vibration motions of $v_{n}$ for 7:7 $\left(C_{\mathrm{i}}\right)$.

Author Contributions: S.H. formulated the project. T.N. and S.H. optimized all compounds. T.N. calculated the $\rho_{\mathrm{b}}\left(\boldsymbol{r}_{\mathrm{c}}\right), H_{\mathrm{b}}\left(\boldsymbol{r}_{\mathrm{c}}\right)-V_{\mathrm{b}}\left(\boldsymbol{r}_{\mathrm{c}}\right) / 2\left(=\left(\hbar^{2} / 8 m\right) \nabla^{2} \rho_{\mathrm{b}}\left(\boldsymbol{r}_{\mathrm{c}}\right)\right)$, and $H_{\mathrm{b}}\left(\boldsymbol{r}_{\mathrm{c}}\right)$ values, evaluated the QTAIMDFA parameters, and analyzed the data. S.H. and T.N. organized the data for writing, and T.N. wrote the paper. All authors have read and agreed to the published version of the manuscript.

Funding: This research received no external funding.

Data Availability Statement: Data are contained within the article or the Supplementary Materials.

Acknowledgments: The authors are very grateful to Waro Nakanishi of Wakayama University for discussing the dynamic and static nature of $\pi \cdots \pi$ interactions in helicenes and dimers, elucidated with QTAIM-DFA.

Conflicts of Interest: The authors declare no conflict of interest.

\section{References}

1. Shen, Y.; Chen, C.F. Helicenes: Synthesis and Applications. Chem. Rev. 2012, 112, 1463-1535. [CrossRef] [PubMed]

2. Chen, C.F.; Shen, Y. Helicene Chemistry: From Synthesis to Applications; Springer: Berlin, Germany, 2017. [CrossRef]

3. Dhbaibi, K.; Favereau, L.; Crassous, J. Enantioenriched Helicenes and Helicenoids Containing Main-Group Elements (B, Si, N, P). Chem. Rev. 2019, 119, 8846-8953. [CrossRef] [PubMed]

4. Tani, F.; Narita, M.; Murafuji, T. Helicene Radicals: Molecules Bearing a Combination of Helical Chirality and Unpaired Electron Spin. ChemPlusChem 2020, 85, 2093-2104. [CrossRef] [PubMed]

5. Jakubec, M.; Storch, J. Recent Advances in Functionalizations of Helicene Backbone. J. Org. Chem. 2020, 85, 13415-13428. [CrossRef]

6. Ren, M.; Wang, J.; Xie, X.; Zhang, J.; Wang, P. Double-Helicene-Based Hole-Transporter for Perovskite Solar Cells with 22\% Efficiency and Operation Durability. ACS Energy Lett. 2019, 4, 2683-2688. [CrossRef]

7. Xu, N.; Li, Y.; Ricciarelli, D.; Wang, J.; Mosconi, E.; Yuan, Y.; de Angelis, F.; Zakeeruddin, S.M.; Grätzel, M.; Wang, P. An Oxa[5]Helicene-Based Racemic Semiconducting Glassy Film for Photothermally Stable Perovskite Solar Cells. iScience 2019, 15, 234-242. [CrossRef] 
8. Wang, J.; Shi, H.; Xu, N.; Zhang, J.; Yuan, Y.; Lei, M.; Wang, L.; Wang, P. Aza[5]Helicene Rivals N-Annulated Perylene as $\pi$-Linker of D- $\pi$-D Typed Hole-Transporters for Perovskite Solar Cells. Adv. Funct. Mater. 2020, 30, 2002114. [CrossRef]

9. Wei, Y.; Zheng, A.; Xie, X.; Zhang, J.; He, L.; Wang, P. A Pyrrole-Bridged Bis(Oxa[5]Helicene)-Based Molecular Semiconductor for Efficient and Durable Perovskite Solar Cells: Microscopic Insights. ACS Mater. Lett. 2021, 3, 947-955. [CrossRef]

10. Wang, J.; Wang, Y.; Xie, X.; Ren, Y.; Zhang, B.; He, L.; Zhang, J.; Wang, L.D.; Wang, P. A Helicene-Based Molecular Semiconductor Enables $85^{\circ} \mathrm{C}$ Stable Perovskite Solar Cells. ACS Energy Lett. 2021, 6, 1764-1772. [CrossRef]

11. Tsujihara, T.; Inada-Nozaki, N.; Takehara, T.; Zhou, D.Y.; Suzuki, T.; Kawano, T. Nickel-Catalyzed Construction of Chiral 1-[6]Helicenols and Application in the Synthesis of [6]Helicene-Based Phosphinite Ligands. Eur. J. Org. Chem. 2016, 2016, 4948-4952. [CrossRef]

12. Yamamoto, K.; Shimizu, T.; Igawa, K.; Tomooka, K.; Hirai, G.; Suemune, H.; Usui, K. Rational Design and Synthesis of [5]Helicene-Derived Phosphine Ligands and Their Application in Pd-Catalyzed Asymmetric Reactions. Sci. Rep. 2016, 6, 36211. [CrossRef]

13. Demmer, C.S.; Voituriez, A.; Marinetti, A. Catalytic Uses of Helicenes Displaying Phosphorus Functions. Comptes Rendus Chim. 2017, 20, 860-879. [CrossRef]

14. Cauteruccio, S.; Licandro, E.; Panigati, M.; D'Alfonso, G.; Maiorana, S. Modifying the Properties of Organic Molecules by Conjugation with Metal Complexes: The Case of Peptide Nucleic Acids and of the Intrinsically Chiral Thiahelicenes. Coord. Chem. Rev. 2019, 386, 119-137. [CrossRef]

15. Beránek, T.; Žádný, J.; Strašák, T.; Karban, J.; Císařová, I.; Sýkora, J.; Storch, J. Synthesis of a Helical Phosphine and a Catalytic Study of Its Palladium Complex. ACS Omega 2020, 5, 882-892. [CrossRef]

16. Medena, C.; Aubert, C.; Derat, E.; Fensterbank, L.; Gontard, G.; Khaled, O.; Ollivier, C.; Vanthuyne, N.; Petit, M.; Barbazanges, M. Helical Bisphosphinites in Asymmetric Tsuji-Trost Allylation: A Remarkable P:Pd Ratio Effect. ChemCatChem 2021, 13, 4543-4548. [CrossRef]

17. Kel, O.; Fürstenberg, A.; Mehanna, N.; Nicolas, C.; Laleu, B.; Hammarson, M.; Albinsson, B.; Lacour, J.; Vauthey, E. Chiral Selectivity in the Binding of [4]Helicene Derivatives to Double-Stranded DNA. Chem. Eur. J. 2013, 19, 7173-7180. [CrossRef]

18. Kawara, K.; Tsuji, G.; Taniguchi, Y.; Sasaki, S. Synchronized Chiral Induction between [5]Helicene-Spermine Ligand and B-Z DNA Transition. Chem. Eur. J. 2017, 23, 1763-1769. [CrossRef]

19. Kalachyova, Y.; Guselnikova, O.; Elashnikov, R.; Panov, I.; Žádný, J.; Církva, V.; Storch, J.; Sykora, J.; Zaruba, K.; Švorčík, V.; et al. Helicene-SPP-Based Chiral Plasmonic Hybrid Structure: Toward Direct Enantiomers SERS Discrimination. ACS Appl. Mater. Interfaces 2019, 11, 1555-1562. [CrossRef]

20. Schulte, T.R.; Holstein, J.J.; Clever, G.H. Chiral Self-Discrimination and Guest Recognition in Helicene-Based Coordination Cages. Angew. Chem. 2019, 131, 5618-5622. [CrossRef]

21. Petdum, A.; Faichu, N.; Sirirak, J.; Khammultri, P.; Promarak, V.; Panchan, W.; Sooksimuang, T.; Charoenpanich, A.; Wanichacheva N. [5]Helicene-Rhodamine $6 \mathrm{G}$ Hybrid-Based Sensor for Ultrasensitive $\mathrm{Hg}^{2+}$ Detection and Its Biological Applications. J. Photochem. Photobiol. A 2020, 394, 112473. [CrossRef]

22. Gu, X.H.; Lei, Y.; Wang, S.; Cao, F.; Zhang, Q.; Chen, S.; Wang, K.P.; Hu, Z.Q. Tetrahydro[5]Helicene Fused Nitrobenzoxadiazole as a Fluorescence Probe for Hydrogen Sulfide, Cysteine/Homocysteine and Glutathione. Spectrochim. Acta A Mol. Biomol. Spectrosc. 2020, 229, 118003. [CrossRef]

23. Li, J.; Martin, K.; Avarvari, N.; Wäckerlin, C.; Ernst, K.H. Spontaneous Separation of On-Surface Synthesized Tris-Helicenes into Two-Dimensional Homochiral Domains. Chem. Commun. 2018, 54, 7948-7951. [CrossRef]

24. Shiotari, A.; Tanaka, K.; Nakae, T.; Mori, S.; Okujima, T.; Uno, H.; Sakaguchi, H.; Sugimoto, Y. Chiral Discrimination and Manipulation of Individual Heptahelicene Molecules on $\mathrm{Cu}(001)$ by Noncontact Atomic Force Microscopy. J. Phys. Chem. C 2018, 122, 4997-5003. [CrossRef]

25. Zhang, H.; Liu, H.; Shen, C.; Gan, F.; Su, X.; Qiu, H.; Yang, B.; Yu, P. Chiral Recognition of Hexahelicene on a Surface via the Forming of Asymmetric Heterochiral Trimers. Int. J. Mol. Sci. 2019, 20, 2018. [CrossRef]

26. Irziqat, B.; Berger, J.; Mendieta-Moreno, J.I.; Sundar, M.S.; Bedekar, A.V.; Ernst, K.H. Transition from Homochiral Clusters to Racemate Monolayers during 2D Crystallization of Trioxa[11]Helicene on Ag(100). ChemPhysChem 2021, 22, 293-297. [CrossRef]

27. Matsuiwa, K.; Hayashi, S.; Nakanishi, W. Dynamic and Static Behavior of Intramolecular $\pi-\pi$ Interactions in [2.2]- and [3.3]Cyclophanes, Elucidated by QTAIM Dual Functional Analysis with QC Calculations. ChemistrySelect 2017, 2, 1774-1782. [CrossRef]

28. Matsuiwa, K.; Hayashi, S.; Nakanishi, W. Intramolecular $\pi-\pi$ Interactions in Diethanodihydronaphthalene and Derivatives: Dynamic and Static Behavior of the Interactions Elucidated by QTAIM Dual Functional Analysis. ChemistrySelect 2016, 1, 2344-2353. [CrossRef]

29. Matsuiwa, K.; Sugibayashi, Y.; Tsubomoto, Y.; Hayashi, S.; Nakanishi, W. Behavior of Intramolecular $\pi-\pi$ Interactions with Doubly Degenerated Bond Paths between Carbon Atoms in Opposite Benzene Rings of Diethenodihydronaphthalenes by QTAIM Approach. ChemistrySelect 2017, 2, 90-100. [CrossRef]

30. Nakanishi, W.; Hayashi, S.; Narahara, K. Atoms-in-Molecules Dual Parameter Analysis of Weak to Strong Interactions: Behaviors of Electronic Energy Densities versus Laplacian of Electron Densities at Bond Critical Points. J. Phys. Chem. A 2008, 112, 13593-13599. [CrossRef]

31. Nakanishi, W.; Hayashi, S.; Narahara, K. Polar Coordinate Representation of $H_{\mathrm{b}}\left(r_{\mathrm{c}}\right)$ versus $\left(\hbar^{2} / 8 m\right) \nabla^{2} \rho_{\mathrm{b}}\left(r_{\mathrm{c}}\right)$ at BCP in AIM Analysis: Classification and Evaluation of Weak to Strong Interactions. J. Phys. Chem. A 2009, 113, 10050-10057. [CrossRef] 
32. Nakanishi, W.; Hayashi, S. Atoms-in-Molecules Dual Functional Analysis of Weak to Strong Interactions. Curr. Org. Chem. 2010, 14, 181-197. [CrossRef]

33. Nakanishi, W.; Hayashi, S. Dynamic Behaviors of Interactions: Application of Normal Coordinates of Internal Vibrations to AIM Dual Functional Analysis. J. Phys. Chem. A 2010, 114, 7423-7430. [CrossRef] [PubMed]

34. Nakanishi, W.; Hayashi, S.; Matsuiwa, K.; Kitamoto, M. Applications of Normal Coordinates of Internal Vibrations to Generate Perturbed Structures: Dynamic Behavior of Weak to Strong Interactions Elucidated by Atoms-in-Molecules Dual Functional Analysis. Bull. Chem. Soc. Jpn. 2012, 85, 1293-1305. [CrossRef]

35. Nakanishi, W.; Hayashi, S. Role of $\mathrm{d} G / \mathrm{d} w$ and $\mathrm{d} V / \mathrm{d} w$ in AIM Analysis: An Approach to the Nature of Weak to Strong Interactions. J. Phys. Chem. A 2013, 117, 1795-1803. [CrossRef]

36. Bader, R.F.W. Atoms in Molecules. A Quantum Theory; Oxford University Press: Oxford, UK, 1990.

37. Matta, C.F.; Boyd, R.J. An introduction to the quantum theory of atoms in molecules. In The Quantum Theory of Atoms in Molecules: From Solid State to DNA and Drug Design; Wiley: Weinheim, Germany, 2007. [CrossRef]

38. Nakanishi, W.; Hayashi, S. Perturbed Structures Generated Using Coordinates Derived from Compliance Constants in Internal Vibrations for QTAIM Dual Functional Analysis: Intrinsic Dynamic Nature of Interactions. Int. J. Quantum Chem. 2018, 118, e25590. [CrossRef]

39. Grunenberg, J.; Brandhorst, K. Compliance 3.0.2 program. Available online: http://www.oc.tu--bs.de/Grunenberg/compliance html (accessed on 14 December 2021).

40. Brandhorst, K.; Grunenberg, J. Efficient Computation of Compliance Matrices in Redundant Internal Coordinates from Cartesian Hessians for Nonstationary Points. J. Chem. Phys. 2010, 132, 184101. [CrossRef]

41. Brandhorst, K.; Grunenberg, J. How Strong Is It? The Interpretation of Force and Compliance Constants as Bond Strength Descriptors. Chem. Soc. Rev. 2008, 37, 1558-1567. [CrossRef]

42. Grunenberg, J. Ill-Defined Concepts in Chemistry: Rigid Force Constants vs. Compliance Constants as Bond Strength Descriptors for the Triple Bond in Diboryne. Chem. Sci. 2015, 6, 4086-4088. [CrossRef]

43. Grunenberg, J. Direct Assessment of Interresidue Forces in Watson-Crick Base Pairs Using Theoretical Compliance Constants. J. Am. Chem. Soc. 2004, 126, 16310-16311. [CrossRef]

44. Grunenberg, J.; Barone, G. Are Compliance Constants Ill-Defined Descriptors for Weak Interactions? RSC Adv. 2013, 3, 4757-4762. [CrossRef]

45. Taylor, W.J.; Pitzer, K.S. Vibrational Frequencies of Semirigid Molecules: A General Method and Values for Ethylbenzene. J. Res. Natl. Bur. Stand. 1947, 38, 1-17. [CrossRef]

46. Konkoli, Z.; Cremer, D. A New Way of Analyzing Vibrational Spectra. I. Derivation of Adiabatic Internal Modes. Int. J. Quantum Chem. 1998, 67, 1-9. [CrossRef]

47. Grunenberg, J.; Goldberg, N. How Strong Is the Gallium $\equiv$ Gallium Triple Bond? Theoretical Compliance Matrices as a Probe for Intrinsic Bond Strengths. J. Am. Chem. Soc. 2000, 122, 6045-6047. [CrossRef]

48. Grunenberg, J.; Streubel, R.; Frantzius, G.V.; Marten, W. The Strongest Bond in the Universe? Accurate Calculation of Compliance Matrices for the Ions $\mathrm{N}_{2} \mathrm{H}^{+}, \mathrm{HCO}^{+}$, and $\mathrm{HOC}^{+}$. J. Chem. Phys. 2003, 119, 165-169. [CrossRef]

49. Xie, Y.; Schaefer, H.F. The Characterization of Metal-Metal Bonds in Unsaturated Binuclear Homoleptic Transition Metal Carbonyls. The Compliance Matrix. Z. Phys. Chem. 2003, 217, 189-203. [CrossRef]

50. Frisch, M.J.; Trucks, G.W.; Schlegel, H.B.; Scuseria, G.E.; Robb, M.A.; Cheeseman, J.R.; Scalmani, G.; Barone, V.; Mennucci, B.; Petersson, G.A.; et al. Gaussian 09 (Revision D.01); Gaussian, Inc.: Wallingford, CT, USA, 2009.

51. Zhao, Y.; Truhlar, D.G. The M06 Suite of Density Functionals for Main Group Thermochemistry, Thermochemical Kinetics, Noncovalent Interactions, Excited States, and Transition Elements: Two New Functionals and Systematic Testing of Four M06-Class Functionals and 12 Other Functionals. Theor. Chem. Acc. 2008, 120, 215-241. [CrossRef]

52. Vydrov, O.A.; Scuseria, G.E. Assessment of a Long-Range Corrected Hybrid Functional. J. Chem. Phys. 2006, 125, 234109. [CrossRef]

53. Hayashi, S.; Nishide, T.; Ueda, K.; Hayami, K.; Nakanishi, W. Effects from Basis Sets and Levels of Calculations on the Nature of Interactions Predicted by QTAIM-Dual Functional Analysis with QTAIM Functions. ChemistrySelect 2019, 4, 6198-6208. [CrossRef]

54. Ivanov, M.D.; Kirina, Y.V.; Novikov, A.S.; Starova, G.L.; Kukushkin, V.Y. Efficient $\pi$-stacking with benzene provides $2 D$ assembly of trans-[ $\left.\mathrm{PtCl}_{2}\left(p-\mathrm{CF}_{3} \mathrm{C}_{6} \mathrm{H}_{4} \mathrm{CN}\right)_{2}\right]$. J. Mol. Struct. 2016, 1104, 19-23. [CrossRef]

55. Mukhacheva, A.A.; Komarov, V.Y.; Kokovkin, V.V.; Novikov, A.S.; Abramov, P.A.; Sokolov, M.N. Unusual p-p interactions directed by the $\left.\left[\left\{\left(\mathrm{C}_{6} \mathrm{H}_{6}\right) \mathrm{Ru}\right\}_{2} \mathrm{~W}_{8} \mathrm{O}_{30} \mathrm{OH}\right)_{2}\right]^{6-}$ hybrid anion. CrystEngComm 2021, 23, 4125-4135. [CrossRef]

56. Biegler-König, F.; Schönbohm, J. The AIM2000 Program (Version 2.0). Available online: http:/ /www.aim2000.de (accessed on 14 December 2021).

57. Biegler-König, F. Calculation of atomic integration data. J. Comput. Chem. 2000, 21, 1040-1048. [CrossRef]

58. Keith, T.A. AIMAll (Version 17.11.14), TK Gristmill Software, Overland Park, KS, USA. 2017. Available online: http://aim. tkgristmill.com (accessed on 14 December 2021).

59. Kay, M.I.; Okaya, Y.; Cox, D.E. A Refinement of the Structure of the Room-Temperature Phase of Phenanthrene, $\mathrm{C}_{14} \mathrm{H}_{10}$, from X-ray and Neutron Diffraction Data. Acta Crystallogr. Sect. B Struct. Crystallogr. Cryst. Chem. 1971, 27, 26-33. [CrossRef] 
60. Lakshman, M.K.; Kole, P.L.; Chaturvedi, S.; Saugier, J.H.; Yeh, H.J.C.; Glusker, J.P.; Carrell, H.L.; Katz, A.K.; Afshar, C.E.; Dashwood, W.M.; et al. Methyl Group-Induced Helicity in 1,4-Dimethylbenzo[c]Phenanthrene and Its Metabolites: Synthesis, Physical, and Biological Properties. J. Am. Chem. Soc. 2000, 122, 12629-12636. [CrossRef]

61. Bédard, A.C.; Vlassova, A.; Hernandez-Perez, A.C.; Bessette, A.; Hanan, G.S.; Heuft, M.A.; Collins, S.K. Synthesis, Crystal Structure and Photophysical Properties of Pyrene-Helicene Hybrids. Chem. Eur. J. 2013, 19, 16295-16302. [CrossRef]

62. Yoshida, Y.; Nakamura, Y.; Kishida, H.; Hayama, H.; Nakano, Y.; Yamochi, H.; Saito, G. Racemic Charge-Transfer Complexes of a Helical Polycyclic Aromatic Hydrocarbon Molecule. CrystEngComm 2017, 19, 3626-3632. [CrossRef]

63. Fujino, S.; Yamaji, M.; Okamoto, H.; Mutai, T.; Yoshikawa, I.; Houjou, H.; Tani, F. Systematic Investigations on Fused $\pi$-System Compounds of Seven Benzene Rings Prepared by Photocyclization of Diphenanthrylethenes. Photochem. Photobiol. Sci. 2017, 16, 925-934. [CrossRef]

64. Mori, K.; Murase, T.; Fujita, M. One-Step Synthesis of [16]Helicene. Angew. Chem. 2015, 127, 6951-6955. [CrossRef]

65. Bas, G.L.; Navaza, A.; Mauguen, Y.; Rango, C.D. 10-Helicene, C42H24. Cryst. Struct. Commun. 1976, 5, $357-361$.

66. Bas, G.L.; Navaza, A.; Knossow, M.; Rango, C.D. 11-Helicene, C46H26. Cryst. Struct. Commun. 1976, 5, $713-718$.

67. Rulíšek, L.; Exner, O.; Cwiklik, L.; Jungwirth, P.; Starý, I.; Pospíšil, L.; Havias, Z. On the Convergence of the Physicochemical Properties of [n]Helicenes. J. Phys. Chem. C 2007, 111, 14948-14955. [CrossRef]

68. Krygowski, T.M. Crystallographic Studies of Inter- and Intramolecular Interactions Reflected in Aromatic Character of $\pi$-Electron Systems. J. Chem. Inf. Comput. Sci. 1993, 33, 70-78. [CrossRef]

69. Bader, R.F.W. Bond Paths Are Not Chemical Bonds. J. Phys. Chem. A 2009, 113, 10391-10396. [CrossRef]

70. Grimme, S.; Mück-Lichtenfeld, C.; Erker, G.; Kehr, G.; Wang, H.; Beckers, H.; Willner, H. When Do Interacting Atoms Form a Chemical Bond? Spectroscopic Measurements and Theoretical Analyses of Dideuteriophenanthrene. Angew. Chem. Int. 2009, 48, 2592-2595. [CrossRef]

71. Cukrowski, I. A Unified Molecular-Wide and Electron Density Based Concept of Chemical Bonding. Wiley Interdiscip. Rev. Comput. Mol. Sci. 2021, e1579. [CrossRef]

72. Pendás, A.M.; Francisco, E.; Blanco, M.A.; Gatti, C. Bond Paths as Privileged Exchange Channels. Chem. Eur. J. 2007, 13, 9362-9371. [CrossRef]

73. Tognetti, V.; Joubert, L. On the Physical Role of Exchange in the Formation of an Intramolecular Bond Path between Two Electronegative Atoms. J. Chem. Phys. 2013, 138, 024102. [CrossRef]

74. Cukrowski, I.; de Lange, J.H.; Adeyinka, A.S.; Mangondo, P. Evaluating Common QTAIM and NCI Interpretations of the Electron Density Concentration through IQA Interaction Energies and 1D Cross-Sections of the Electron and Deformation Density Distributions. Comput. Theor. Chem. 2015, 1053, 60-76. [CrossRef] 